\title{
環境基本法と環境基本計画
}

環境庁環境計画課 小林光

(現・地球環境部環境保全対策課長)

\section{The Basic Environment Law and The Basic Environment Plan}

Hikaru Kobayashi

Strategic Environmental Planning Division,

The Environment Agency

\section{(はじめに)}

ただいまご紹介にあずかりました小林です。環境庁 の企画調整局というところで環境計画課長をしており ます。

今回, 紙パルプ産業の皆様におかれましては, 私ど もが主唱させて頂いている環境月間において大変熱心 に環境に対するところのいろいろな取り組みの普及, 啓発, あるいは最新情報の提供といったたくさんの行 事を考えていらっしゃるということをお聞きして，大 変私どもとしても心強く思っているところであります。 そうしたなかで，わざわざお時間を割いていただき， 私のほうから直接お話をする時間を作っていただいた ということで, 大変光栄に存じております。

本日は大変限られた時間ですから, 質疑応答等もさ せていただくとして，1時間ちょつと私のほうからお 話しを申し上げ，その後，15分ぐらい会場のほうか ら具体的にご質問があればお受けし，私どもの最近の 動き等々を質問に対するお答えということで補足をさ せていただきたいと思います。そういった段取りで, あるいは端折った説明になってわかりにくいところが あろうかと思いますが, ひとつ我慢して聞いていただ ければと思っております。

「環境基本法」あるいは「環境基本計画」というも のが, 最近, 出てきています。この背景には20３0

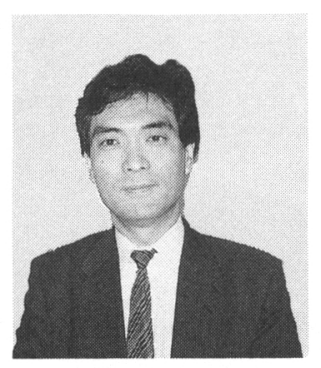

年に 1 回の大きな変化があります。その変化のプロセ スが,まだ終わったわけではもちろんありませんし， またその変化の結果が収穫される, 刈り取られるには, なお，なおその間がある。おそらく，公害対策などに 取り組んできた今までの時間に匹敵するような長い時 間がかかって成果が出てくることになるのではないか と思っておりますが，そうしな大きな時間の流れの中 で, ひとつ今, 着々と変化が進んでいることにつきま して, せっかくの機会ですので聞いてお帰りになって いただければ大変有り難いと考えております。

“変化”というのは何かということが本日のテーマ になろうかと思います。お手元には，3種類のパンフ レットが配られています。1つは「環境基本計画のあ らまし」という短い 8 頁のパンフレットです。もう 1 つは, 少し長いパンフレットで, 「環境基本計画を考 える」(写真) というものです。これは24頁あります。 そして, あと小さなパンフレット, 私どもは「率先実 行計画」といっておりますが, これは政府部門だけの 計画なので, これは, 後で, 最近のホット・イッシュ 一としてご説明申し上げようと思いますが，そういつ た事についてのパンフレットと合せて 3 種類あります。 本日は, この中の厚いほうの「環境基本計画を考え る」というパンフレットを見ながら，大変端折った説 明になりますが, 要所だけをピックアップしてご説明 することにしたいと思います。 


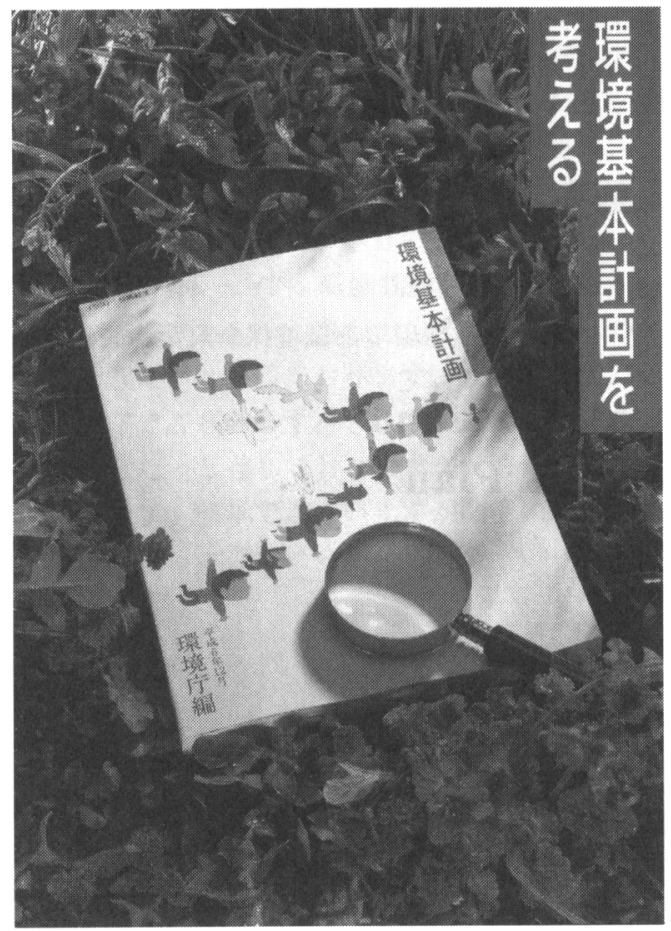

さて, いま起きている変化の背景というものが, 当 然この「環境基本計画」の前提にあるわけです。また 「環境基本法」という法律の前提にあるわけでありま すが, それは, 環境問題の性質が, だいぶ昔とは変わ つてきたということだと思います。この問題の性質に 見合った取り組みの仕方というのをやっていかないと 解決がおぼつかない，ということであります。

ここでは，まず国全体の話ですから，大づかみにそ の問題の性質を 3 つに捉えているわけです。皆様方の 実際の工場におきますところの取り組み方の違いとい ったことにもあるいは反映して起こっていると思いま すが, それにはこのパンフレットに触れていませんけ れども, 後で時間があれば口頭で補ってみないと思い ます。

\section{1. 環境基本計画の背景}

\section{1 環境はすべての要素が関係し合った織物}

まず，大づかみに見なときの問題の性質が昔と違つ てきたということがこの変化の中身にあるわけですが, それは何かということで, ここでは 3 点書いてありま す。

1つは，環境はすべての要素が関係し合ったいわば 織物みないなものになっているという認識であります。 これは，別に，人間の活動が盛んになろうがなるまい
が，人間がいようがいまいが，これは大昔から変わら ないのであります。しかし，大事なことは，いわば生 態系といいますか, 環境の要素のその間のいろいろな 複雑な有機的な関係といったものが壊れるというよう なことに伴う問題が現実に起きてきたというところが この認識のポイントになるのかなと思います。煎じ詰 めて言いますと, 逆に, 1 筒所を吒いて, そこで解決 をしようというふうに思いましても, いわばモグラ叨 きみたいになってしまって, 問題を 1 箇所から別の場 所に移しただけというようなことも起こってくるわけ でありますが，現にそういう問題が起きてきていると いうことがいえると思います。

たとえば，1つの卑近な例ですが，私どもはすでに 公害対策の中で経験をしてきたことですから, 皆様方 の会社でも関係があると思いますが，たとえば，昔， 硫黄酸化物の大気污染が酷かったわけですね。そうい う大気污染対策のためにどういう対策をとつたか。い ろいろな対策がもちろんあるわけでありますが，1つ は技術的なオプションとしては，煙突を高くするとい う方法がありました。煙突を高くしますと, 煙が落ち てくる場所がだいぶ遠くになる，その間にはその煙は 薄まるということでありまして，むずかしい言葉で言 いますと「最大着地濃度」というようなことをいうわ けでありますが, この「最大着地濃度」というのが 「薄まる」ということであります。そうしますと, 同 じ排出量であっても，煙突を高くするだけで被害の方 は減ってくるということであるわけで, それはそれで ひとつの合理的な対策だったわけです。

しかし，そういうことをみんながしたらどうなるの か, とこういうことであります。やはり最大着地濃度 を工場分だけ足していけば，たとえ 1 個ずつの工場の 着地濃度が小さくても, 実際に合計としては大変高い 濃度が出てくるということが現に起きてきたわけです。 そういうことで, 総量規制の実施ということになった のです。

さらに，日本の中でも現実にも心配されております が，特に欧米各国では心配されておりますのは，例の 酸性雨です。これは，もう大気污染という範疇を越え， むしろ自然破壞，あるいは場合によっては，財産被害， たとえば建物だとか, あるいは昔の歴史的な記念物が ありますし，一説には, 酸性雨の過程で, たとえば水 が酸性化すると有害な重金属類が析出してきて飲み水 を経由した健康影響もあるのだというような説もあり ますが，いずれにしても，そういう幅広い影響という ものを生むようになったわけです。

環境というのは, 普通の大気污染の対策の考之方か 


\section{背景と意義}

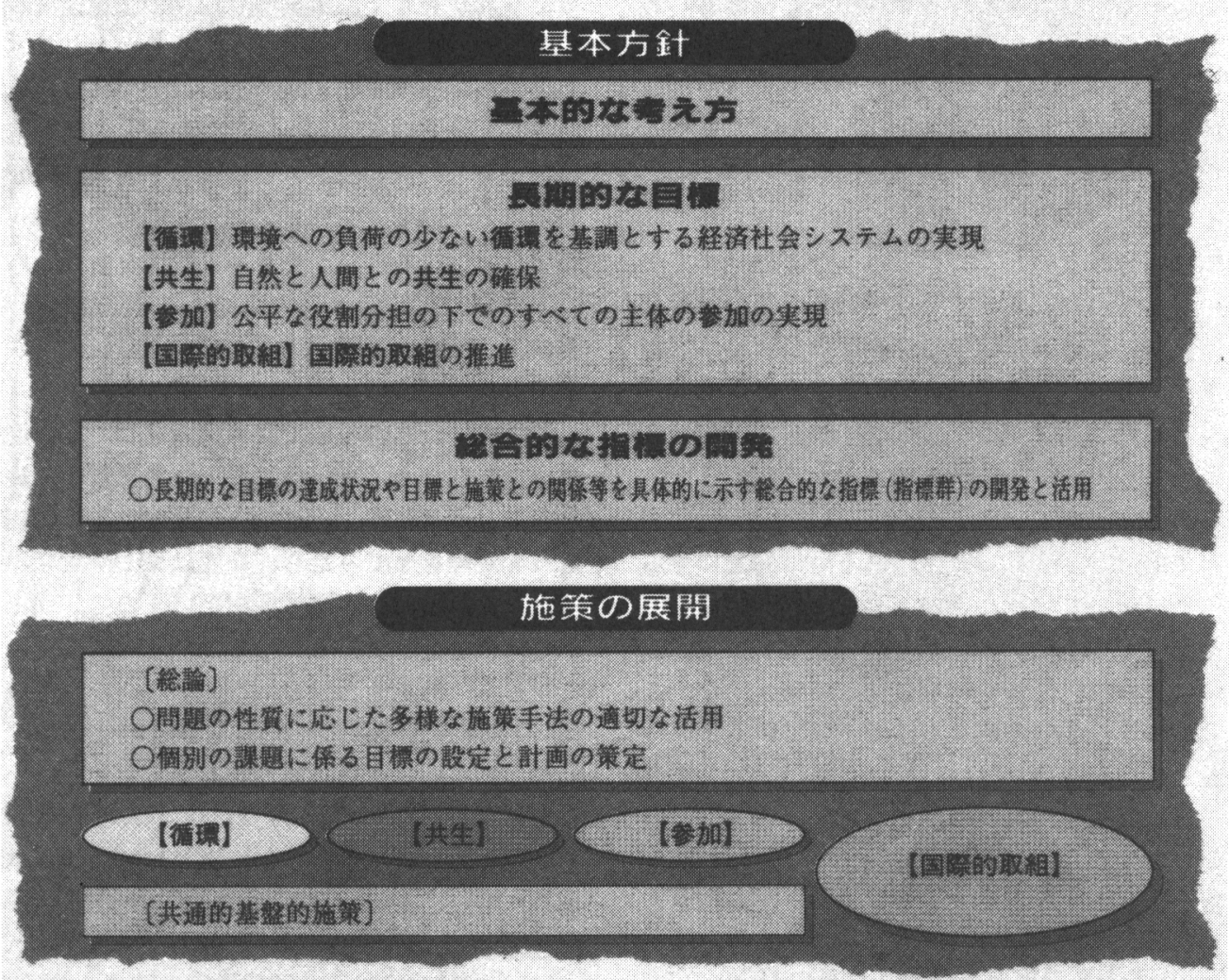

\section{計画の効果的実施}

図 1 環境基本計画の構成

らすれば，空気は無限の容量を持った，つまりキャパ シティがすごく大きなゴミ捨て場だと思われてきまし た。一つひとつの工場にとってみれば，確かにその通 りだと思うのですが，それをみんなが利用しているう ちに，どうもそうではなくなってしまった。無限の容 量のゴミ捨て場ではなくて，それがその中で変化して， 結局は，人間の世界の方にしっぺ返しをしてくる。環 境のつながりから，そういうことが起きてくるわけで す。

古典的な例は，水俣病の問題で，単に工場排水を直 接飲んだというわけではないのですね。工場排水が川 に入って，それを上水道としてみんなが飲んな゙から発 病したというものではなくて，実際には，工場排水が， さらに生物の中で濃縮されて, 大変高い濃度で有機水 銀を含むようになって，それをたくさん食べた方々が 発病した。こういう生態系の働きは, 端的に言えば, 生物濃縮といいますか, そういった特別の働きを抜き
にしては起きなかった問題であります。

そういうわけで，一つの環境メディアといいますか, 大気とか水とか，あるいは一つの局所的な問題だけを 見張っていたら，実はモグラ叨きといいますか，他の 所に問題を移しているだけというようなことも起こる わけであり，全体的な目配りが，現にますます必要に なってきたということがいえるかと思います。

たとえばゴミの問題にしても，ゴミを減らすのは， 最近の問題意識ですね。ゴミの問題については, 今ま での発想は，ゴミの処分場がない，あるいは処分をし ようと思うと大変高いお金が掛かると，だからゴミ対 策をしなければいけないといった問題でした。狭い範 囲で考えればそういうことであるわけですが, これか らはそれだけの文脈ではなくて，なとえばそれを温暖 化対策の文脈に結びつけていかなければいけないとい うようなことにもなってくるわけです。

温暖化対策自身も，これは，環境問題としてみます 
と, 単に二酸化炭素を吸って呼吸が苦しくなるという ものではないのでして，もっと幅広い間接的な生態系 を介した，あるいは気候のシステムを介した影響，あ るいは農業とかそういったシステムを擋乱するという ようなことに影響してくるもので，これも大きな広い 環境全体を見渡して，はじめて適切な対策がとれてく る問題だということが言えると思います。

工場の中でも，皆様方は日頃から熱心にやられてい るので釈迦に説法ということになろうかと思いますが, 敢えていわせていただきますと，やはり大気の対策だ けをとるとか, たとえば紙パルプ産業の場合には, 昔 から水質污濁ということで, 大変たくさんの環境投資 をされてきたわけですが，たとえば，水質污濁だけを 考えるというのでは, 実は最適化というのができない 可能性もあると思うのです。

公害対策のレベルが低いとき, あるいは緊急にやら なければいけないというときは，それぞれ問題になっ たところだけを吒くということもあるのでしょう。し かし, これからは, 全体の環境負荷といいますか, こ ういったものを一番合理的な方法で下げていくという ことを考えていかなければいけないと思います。場合 によっては, 製造工程自身の変更だとか, あるいは原 材料といいますか，工程に入ってきますところの原材 料の選択といったようなことも変えていくとか，ある いは原材料のさらに上流, きっとこの環境月間の中の いろいろな講演会の中でも話があると思いますが, た とえば紙でいえば，どんなところから紙の原料を買っ てくるのか, どこの森から伐ってくるのか, またその 森の管理はどうするのかというようなこと, これも， 実は立派な環境対策であり，工場だけを見てはいけな いわけでありますが，そういうようなことまで考えて， 最適化をしていく必要があると思うのです。

日本の場合には，わりとそういうふうになってきた のだろうと思いますが, アメリカなどは最近, その点 にすごく力を入れています。私も地方の現場に 2 年ほ どいたことがありますが，たとえば立入検査というの をかなり丁寧にやります。アメリカの立入検査がどう なのかということを聞いて調べたことがありますが, 日本と違って, わりとぺーパー主義といいますか, 測 定結果などを見ていくことが多いのですね。実際に立 ち入りして，サンプリングをして，むずかしい言葉で いうと「検体収去」という，たとえばゴミのサンプル をとる，あるいは水のサンプルをとるというようなこ とは米国はあまりしないのです。どちらかというと帳 簿などを見てやる。

帳簿に法律違反の事実を書いておく会社は，あまり
いないですから (笑), どういうことが起こるかとい うと, 周りの住民が,「これはおかしい」と苦情を言 ったり何かをして, 事実明々白々の法律違反が起こっ てから取締をして, 事後的な, そのかわり日本と違つ て大変高い罰金などをかけるわけです。今年はいくら 徴収したかというような統計が堂々と，たとえば環境 保護庁などの広報誌などには書いてあるわけです。大 変桁違いの罰金であります。つまり，そういう事後的 な示しを付けるというやり方で担保をとっているわけ でありまして，だいぶ日本とは違うなと思うのです。 そのアメリカが最近, 反省しているのは, まさにその ようなことです。

たとえば，水の検査で立入検査をして法律違反を見 つけた。だから，さっそく処理施設を造って処理をち やんとしろという。それで一生㦟命企業は処理施設を 造って処理をしてみたら，今度はゴミが出てきてしま つた。それで，今度は大変だというので，ゴミの部局 が立入検査をして，これはちょつと有害廃棄物だから こうしろ，ああしろ，という。そういうのを最初から 聞いていたら，たとえばゴミを出ないようにする方法 とか，あるいは水質污濁がそもそも生じないような工 程をとったほうが安かったのかもしれません。ですが, そういうふうにバラバラと指導されて, 問題が起きて から，それこそ最初に申し上げましたように，モグラ 吒きのように対応している。そのやり方がよくないと いうことで，最近は大変反省をしておりまして，大き な流れとしては, 大気の立入検査, 水の立入検査も, ゴミの, 産廃の立入検査も一緒にして, 全体として, 環境負荷を減らすような技術的なアドバイスをしてい くというようなことが新しい方向として打ち出されて おります。産業界も大变歓迎をしておりますし，立入 検査をする担当の方々もそれが本来よかったのかなと いうふうに思ったりもしているようです。

しかし，これはむしろ日本の場合には従来から，そ ういうふうに意識をしてきたかは別として，わりと従 来からその方向にあると思うのですね。日本の場合に は, 法令違反を起こさせないというようなやり方で, それは企業にとっては，根ほり葉ほりいろいろ聞かれ たり，アドバイスを受けたりということになってしま うのかもしれませんが，また，外から見れば，それが 官民の癒着とかということに見えるのかもしれません が,そういうわりときめ細かなやり方をしてきたわけ だと思います。それにしても，自発的にそういうよう な方法をアメリカがとりだしたということは，まずは じめにご報告をしておきたい点であります。

環境問題というのは, 大気だけで起こるわけでもな 


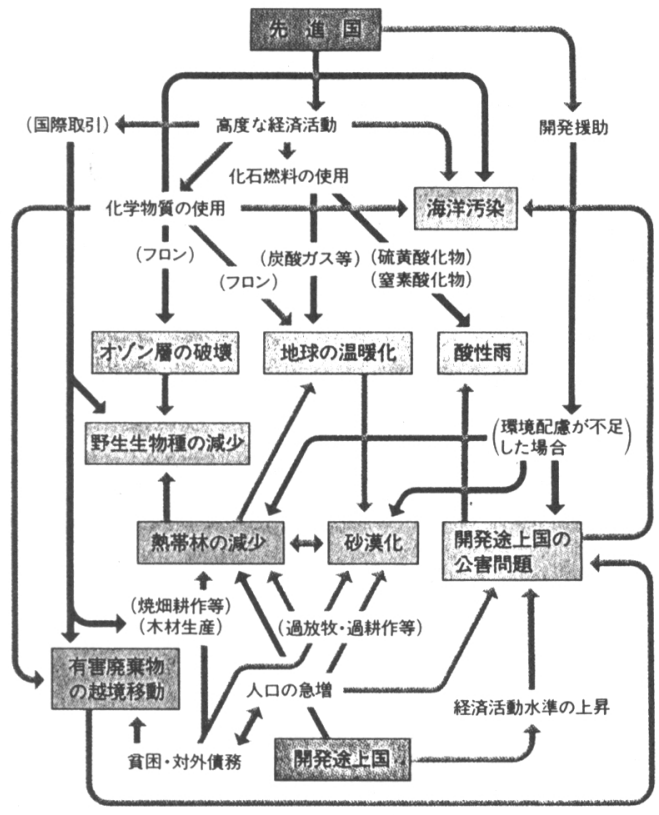

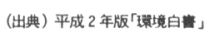

図 2 「問題群」としての地球環境問題

い，水だけでも起こるわけでもない，ひとつのシステ ムになっているわけであり，全体的な目配りがいると いう点に起因するのだと思うわけです。工場というの も，ひとつの小さな人間関係でありますが，そのなか での最適化，ただのモグラ吒きではない対応というも のが当然に必要になってくるのではないかと思うわけ です。

\section{2 当たり前のことも罪つくり}

もう一つは, 当なり前の行為が環境に影響を持って きたということを申し上げます。これも大変大きな問 題であります。

昔は，硫黄酸化物の対策の場合には，たとえば川崎 とか四日市とか, 煙突にすると 10 本ぐらい対策をと つてもらうと, 実際には, 地域の全体の総排出量の 9 割ぐらい，あるいは8割ぐらいに対策をとったことに なってしまうというような具合に, 特定の大規模な発 生源が卓越していたのです。そしてそこからの影響で 公害が起きるというようなことがあったわけです。紙 パルプの産業の場合でも, やはり大きな水質污濁発生 源ということで大変厳しい対策をかつてとらされたこ ともあろうと思いますが, 水の分野で見ても, 特定の 発生源が大きなシェアを占めるということがあったわ けでありますが，それがだんだん変わってきました。

それでは，水のところを見てみますとどうか。図 3 の下の絵を見ていただきますと, 東京湾への水質污濁
東京周辺のNOx排出量の内訳 (平成 2 年度)

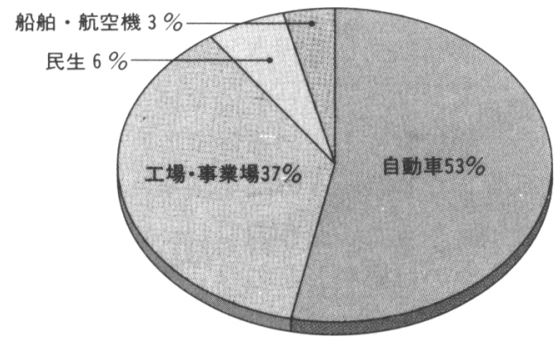

東京湾への水質污濁負荷量 (COD)の内訳 (平成元年度)

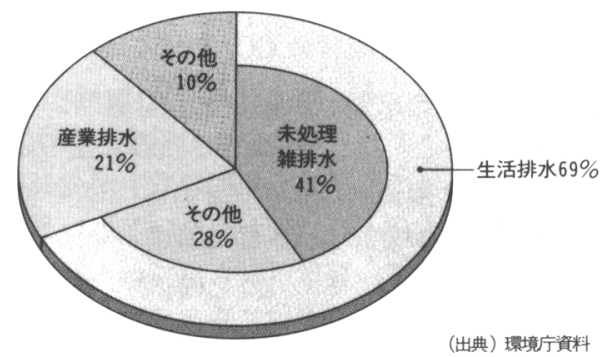

(出典) 環境庁資料

図 3 通常の事業活動や日常生活に起因する環境負荷

の流入負荷量が書いてありますね。これは，いわゆる $\mathrm{COD}$, 有機物質の中での量ですね。計り方によって $\mathrm{BOD}$ とか COD とかあるのはご存じの通りですが, この COD で見たときの東京湾に流入する有機污濁物 質の量なのです。これで見ますと，なんと生活排水系 というのが約 7 割でありまして，産業系のものはもう 2 割にまで減ってしまったということであります。こ こでちょっとびっくりするのは，まだまだ生活排水で 末処理の雑排水というのが多いということです。これ は，まだ合併浄化槽だとか，家庭でできる対策もいろ いろありますし，あるいは下水道といったものをもつ と普及をしないといけない，社会資本をもつと充実し ないといけないということになる。社会資本を充実す ればいいというのは，かけ声をかけるのはやさしいで すけど，結局，それは最終的には国民の税金になりま すから，その税金を配分を変えるなり，あるいはもつ と負担をするなりしなければならない。污染が加速度 的に進んでいくということはないのでしょうけれど， それにしても，未処理雑排水というのがこんなにある というのもひとつの驚きであります。

その他に入っておりますのは, 実は処理後の排水が あります。産業排水は大体処理後の量ですが, 工場の 生まれたばかりの排出量はもっとでかいと思うのです が，要するに処理をされてこれだけ減るということで 
す。

昔というか今もそうですが，民法では，むしろ排水 権といいますか，家庭で生じる污水というものを人の 敷地を突っ切って流したっていいのだといういわば権 利を認めている。要するに, 生活雑排水, あえて污い ものを使ったり流したりというのは当然それで何か起 きれば不法行為ということになるのでしょうけれども， 雑排水を流すというのは権利としてむしろあったぐら いですから，そういう意味で言いますと，今まで慣行

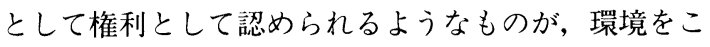
わしているという大変パラドクシカルなことになって きているわけであります。

たとえば，最近流行の $\mathrm{CO}_{2}$ を見てみますと，家庭 から実際に出てくる二酸化炭素の量は, 日本全体の大 体 8 パーセントぐらいだと思うのです。もうすぐ新し い数字, といっても平成 5 年度の数字が発表になると 思いますが，大体それは変わらないと思います。しか し, 電力を使って, 発電所から出ている発電所の $\mathrm{CO}_{2}$ のうち，家庭の使う電力に見合う分，それを家庭のほ うに引っ張ってくると，おそらく 12,3 パーセントが 家庭からの $\mathrm{CO}_{2}$ ということができるのです。

さらに, 産業連関分析というのを使い, 家庭で消費 するいろいろな財，たとえば紙はもちろん産業用に作 るものもあれば，家庭で使われる紙というものもある わけですから, 家庭で使われる紙の分, 家庭のために 産業が作ってあげる，あるいは，それを文房具屋さん に送ったり, 文房具屋さんから家庭へ買っていったり する間に, もちろん商売といいますか, 流通機構, 商 業というような機能を使うわけでありますが，それも みんな電気を使ったり，トラックで運ぶためにはガソ リンを使ったり，ディーゼルだったら軽油を使ったり ということで $\mathrm{CO}_{2}$ が出るわけであります。そういう のをずっと最終的な理由に載せていくのが, 産業連関 分析というものですが，そういうことをやっていきま すと, 45 パーセントぐらいが実は家庭の最終消費に 引っ張られている $\mathrm{CO}_{2}$ だということができるわけで あります。

そういうことで,一番ホットなイッシューでありま すところの温暖化問題を取り上げてみましても，家庭 の影響はすごく大きいわけであります。それだから， 別に家庭が悪いといっているわけではないのです。こ ういう建物でも，こういう事業所，これも当然当たり 前のことでありますが, 電気を使う, あるいは空調を するということで，実は間接的に大きな $\mathrm{CO}_{2}$ を出し ているわけであります。特別のこれだけが悪いという のがあって，これだけをなんとかすれば，対応ができ
るということではなくて，ごくごく当たり前の，それ がたくさん数が集まって問題が起きてきている。その 一個ずつでは何も特に問題が起きるわけでもないです から，罰して止めなければいけないというものでもな い。しかし，それが全部集まると大変なことになる。 こういうわけであります。

その $\mathrm{CO}_{2}$ の話で, ちょつと筋道から逸れてみますと, 産業連関分析をするといろいろおもしろいことがわか ります。いま家庭のシェアが非常に大きいということ を言いましたが, これは, 普通の民生系といいますか, 普通の事務所とか, 普通の一般の活動というのですか, たとえば，紙パルプでいえば，紙を漉くとか，そうい う工程そのものではなくて，管理部門とかありますね。 そういうもののシェアもすごく大きいわけであります。 逆に言えば，そういうところでの対策でよくなる部門 も大きいということです。

そういう意味で, 産業連関分析というのは, 大変精 度は荒いのですが，いわゆるLCA といわれている一 つひとつの商品の生涯にわたるところの環境負荷とい うのを積み上げて計算する手法とは違いまして，それ はごくごく荒っぽいものだと思っていただければいい わけでありますが, 産業関連分析をしますと, しかし, 400 品目ぐらいの分解能が確か一番細かいのであった かと思うのですが, それぞれの商品の環境負荷が分り ます。たとえば遠洋でとれるマグロとお肉と同じ 1 キ ログラムだったらどっちが $\mathrm{CO}_{2}$ をたくさん出すかと いうようなことも計算をされております。肉だと, 確 か 1 キロの肉を食べることは, $\mathrm{CO}_{2}$ でいうと 0.6 キ ログラムですか, マグロ 1 キロは, $\mathrm{CO}_{2}$ というと 2.6 キロだと思います。自動車の場合は, 自動車は 1 キロ とは買えませんから，自動車 1 台でいうと，製造工程 及び消費者に届く輸送までで車 1 台当たり 1.7 トンの $\mathrm{CO}_{2}$ を出しているということです。このようなこと がわかってくるわけであります。

だから，マグロとお肉でいうと，もともと肉のほう がグラム当たりでずっと単価も安いし，タンパク質と してどっちがいいのか，これはまた議論があると思い ますけれども，しかし $\mathrm{CO}_{2}$ の眼鏡で見れば，圧倒的 にマグロのほうが遠洋までいって冷凍して持って来る ということがあまりすから，たくさんの $\mathrm{CO}_{2}$ を出し て生産されているということがわかるわけであります。

ですからお魚を食べるのであれば，なるべく近海も のとか, 旬のものとか, 野菜についてもそうですね。 ここにはキュウリの話が出ていますが (図4)，八ウ スと露地栽培でどれだけ投入エネルギーが違うかとい うことですが，キュウリそのものは，栄養としてみれ 


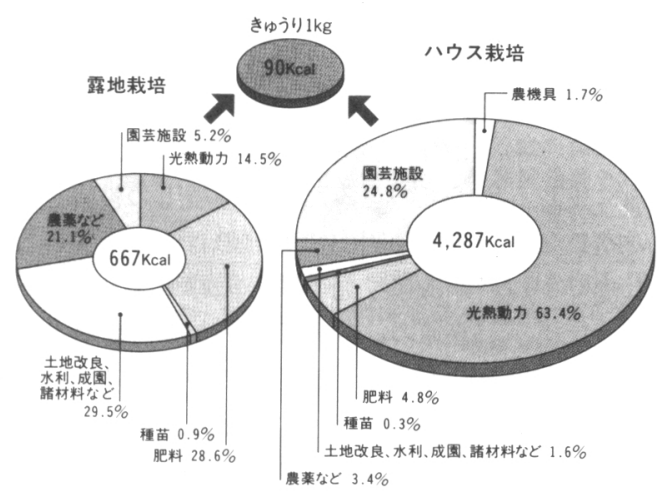

(出典) 科学技術庁の瓷料より環境庁作成。必要なエネルギー量は昭和49年の調査䊅果。

図 4 きゅうり $1 \mathrm{~kg}$ を生産するために必要なエネル ギー

ば, わずか 90 キロカロリーしかないのに, 路地栽培 で作れば 667 キロカロリーの投入ということです (笑)。直接肥料を食べたり, 電気を食べたりすること は人間はできませんから，やはりキュウリが食べたい， あのしゃきしゃきしたのがおいしいなと，こう思って 食べるわけでありますから，キュウリを食べるなとい っているのではないのですが，どうせ食べるなら，路 地のですね。そのかわり路地のできる季節は限られて いるので, 一年中食うことはできませんが, 八ウス栽 培のキュウリを食べると, 環境は本当に, 6 倍とか 7 倍とか悪くするのです。

そういうのを「エコクッキング」なんていうふうに もいいますけれども, 旬のものを選んで食べる。旬の 出盛りのものですね。そういったものを残さず食べる 方が良いのです。

お魚でも，骨は，また骨で揚げたりして食べるとか， いろいろおもしろいことがいわれておりまして, 大変 熱心にそjいjのをやっている方もいます。そjいう 意味でのエコクッキングをするというのは，それは家 計を当然助けることにもなりますし，また環境負荷を 減らすということにもなるわけなのです。

また横道に逸れましたが，しかし，家庭にエコクッ キングをしなさいと，こういうふうに命じる法律はな いわけでありますから，これもなかなかむずかしいも のがあります。

しかし，一つだけ申し上げれば，当たり前の行為が 問題になってきたというのは，逆に言えば，その当た り前の行為を変えることによって—これはむずかし いですよ一， しかし，大きな環境改善も果たせると いうことであります。

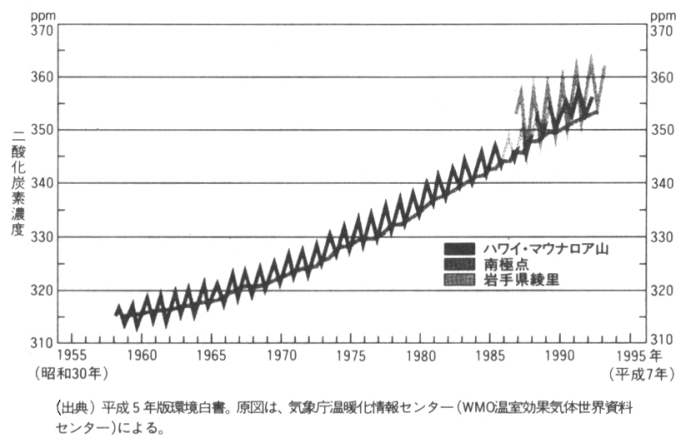

図 5 世界各地の観測所における二酸化炭素濃度の推 移

\section{3 環境問題は国境を越え, 将来の世代に影響が 及ぶ全人類的なもの}

3 点目ですが，これもややこしい問題なのですが, 今までは，危ない物質を吸ったから健康へ影響が起き

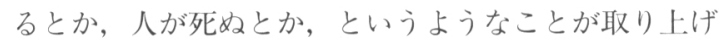
られました。そういう問題は, 原因と結果の関係とい うのはかなりはっきりしているわけですから, 人が倒 れるような話だったら，それは明らかな不法行為とし て行政法などを待たずして, 民法だけで裁判され，負 けるような話がいっぱいある。場合によっては, 刑事 罰とか，公害罪法というのもあるぐらいですが，そう いうようなことにもなりかねないようなことを対象に して，今までは対策をとってきたのです。しかし，そ ういうものだけが環境問題ではないということがはっ きりしてきました。

たとえば，生物の多様性にしてもそうだし，あるい は砂漠化などという問題もそうだと思います。一体,

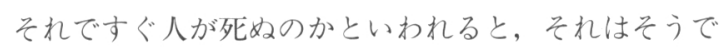
はない。けれども，ちょうど真綿で首を絞めるように， だんだん末来の人類の生きる基盤というものを壞して いってしまうのです。

生物の多様性はどうして大事かということは, “健 全な生態系を保ち自然と共生する取組” と題して私共 の製作した資料に述べておりますが，この多様性がな ぜ大事かというようなことを説明する, あるいは納得 をいただくというのは大変むずかしい。

実利的な話ですとわりとわかりますが，たとえば， 多様性が 10 パーセント減ると何兆円損をするのかと かということだったらこれはわかる。ところが，なか なかそjいうものではない。でないからどうでもいい かというとそうでもない。このへんが大変むずかしい ことであります。砂漠化もそうです。海外の環境など もそうです。日本は海に守られてあまり世界の荒波が 
迫ってこないというふうな物理的な仕組みになってい る上に，お金もたくさんあるから，物がなくなれば， いいものを世界中のどこからか買ってくるということ で斉ませるわけです。しかし，果たしてそれでいいの かどうかという問題があります。また，海外自身で問 題がどこかで起きていることを放置しておいていいの かという問題もあると思うのですが，外国の人のお困 りになっていることというのは, 残念ながら, 日本の 国内法制上，あるいは日本人のモラルとしてみても， 日本人自身の問題とは同列には論じられないのではな いかと思うのが人の常だと思いますね。なかには，そ ういう世界全体を考えて行動される方もいらっしやい ますから，博愛主義で人種に関わらず国籍に関わらず 同じように人間としての権利を享受させるべきだ，主 権国家になってはおかしいという意見の方ももちろん いるわけでありますが，そういう方から見れば，他国 の痛みも自分の痛みも同じかもしれません。しかし， 普通の人は，なかなかそこまでは思っていない。

ところが, 実際には環境というのは一繫がりであり まして，どこかの国が失敗をして，あるいはさぼって， あるいは他の理由で環境対策をとらないことによって， 実は共倒れになるということもたくさんあるわけであ ります。そういった問題が現実に起こった例はたとえ ばチェルノブイリの話などがあります。あれは日本に とってはそれほど切実ではなかったかもしれませんが, ヨーロッパの人にとっては, 大変な問題だったわけで す。いままさに北朝鮮の原子炉の問題など, 何とかし てあげなければと思う気持ちの底にはそういうような こともあるかもしれない。

環境問題も全く同じで，チェルノブイリ自身もそう ですが，そういう問題が起こるような心配はたくさん あるわけであります。熱帯林の話でも，これを全部途 上国が開発のために伐ってしまったということになれ ば，相当な気象秩序に対する擋乱要因になることは間 違いないと思いますし，たとえば遺伝子資源というよ うなことで，いろいろなものを探しに行っているわけ でありますが, 熱帯林の消失はこういった源も失われ てしまうというようなことにもなりかねないわけであ ります。

そう考えますと，環境には国境はないわけであり， 地球全体のことを考えていかなければいけないという ことであります。

国際的な利益を高めるためには, 普通は国際条約を 結んで，その国際条約上の義務を果たすために国内法 をつくるというようなものが普通の発想です。約束を してはじめて, 何か国際的な観点の義務が生じる。そ
うでなければ，国内のことだけを考えればいい。国内 でやったことが利益が外国に及んでいくことも反射的 にあるのかもしれないけれど，そういうことも避けた いというぐらいが伝統的な法律の世界だと思います。 他国に生じる環境上の恵みだとか環境上の被害を防ぐ ということは，やはり国内法制上の目的には書けなか ったのですね。非常に了見の狭い法律であります。そ ういう仕組みが普通の法律の仕組みだと思います。

けれども，それを大きく改めたのが環境基本法です。 ODA 基本法をつくれとかいう声もありますね。外交 専門家などは，これは，つくれないとずっといってき たんです。なぜかというと，外交というのは，ある意 味では夕クティックでありまして，交涉事であります から，日本はこういう方針で外交をやっていくのだと いうことを字に書いて子预示しておいたら，その分だ け手が縛られる。そういうものは，ある意味では，作 戦として満天下に示すものではないのではないかと， こういうようなことです。

\section{2. 環境問題の歴史と政策の進歩}

以上のように，環境基本法の場合にはそういう国際 的な視点ということは抜きにしては語れないというこ とになり，ひとつの章を割いて何条もの条文を当て， 地球環境問題，あるいは地球環境問題にも至らないよ うな途上国での環境破壊への対策もはっきりやってい くこと，政府なり，国民もやっていく，地方公共団体 もやっていく，企業もやっていく，ということがはっ きり書かれているわけです。

やはり法制度の根幹に関わるようなところがあるの で変えなければいけないところは変えるということで, 昭和 40 年に最初, 公害対策基本法ができたと思うの でが，それを大改正してというか，廃止して，環境基 本法ができたわけであります。そして，その環境基本 法をもう少し，具体的に政策の中に落としていくとど ういうことになるか，どういうことをこれからやって いったらいいか，その政策の方向付けといったような ものを形で書き表したものとして，この環境基本計画 が出来たというふうにいうことができると思います。

環境基本法は以上の 3 つの点に鑑みていろいろなこ とを改革したのですが, 図6にこれからの政策の特色 を今までの政策の特色と比べてあります。

法制度が狙うところの 1 つは, 今までは人の健康と か生活環境に生じる被害を防ぐということだったので すが，今までは，被害がなければいいとこういうこと で，いろいろな大きな問題が見過ごされてきた。長い 目で見ると，それは必ずしも得策ではないということ 


\begin{tabular}{|c|c|c|}
\hline & $\begin{array}{l}\text { 公害対策基本法(昭和42年)・ } \\
\text { 自然理境保全法(昭和47年) }\end{array}$ & 棵境基本法(平成 5 年)・環境基本尌画(平成 6 年) \\
\hline 狙 & $\begin{array}{l}\text { 人の健康や生活環境に生 } \\
\text { じる被塞(公䓊)の防止。 } \\
\text { すぐれた自然の風景地の保 } \\
\text { 護と、その利用の促進。 } \\
\text { すぐれた自然環境の保全。 }\end{array}$ & $\begin{array}{l}\text { 日本と地球の環境を守り、環境の恵みを将来世代に継承。このために持続可能な } \\
\text { 社会を築く。 } \\
\text { 環境負荷奇のものを減らし、自然の物質循環を損わないようにする。 } \\
\text { 国土全体にわたって、生物の多様性や、人と自然のふれあいを確保するため、地 } \\
\text { 域の特性に応してて人と自然の共生を進める。 }\end{array}$ \\
\hline 手 & $\begin{array}{c}\text { 環境を害する行為を個別に } \\
\text { 列挙して行う規制が中心。 }\end{array}$ & $\begin{array}{l}\text { 計画を作り、総合的・長期的に幅広い施策を推進。 } \\
\text { 規制によらずとも、関係者が皆、自主的・積極的に参加。 } \\
\text { 経済的措置などを含めて多様な政策手法を活用。 } \\
\text { 国際的な視点に立って取組を推進。 }\end{array}$ \\
\hline
\end{tabular}

図 6 環境基本法の下での政策の特色

であり，発想としては 180 度変わっておりまして，日 本と地球の環境を守って，その環境の恵みを一“恵み” だから,これはプラス思考とし, 被害ではない。增や し伝えていこう。一と考える。たとえば，落第になら なければいい勉強の仕方と, 良い成績をとろうと思う 勉強の仕方は違うわけでありますが, ここでは, 落第 にならなければいいというのではなくて，もっといい 成績を考えましょうということであります。そして将 来の世代にもわたって保障されるようにしていこうと いうことであります。

それも, 日本の環境だけではなく, 地球の環境も (それはもちろん国際的な役割分担のもとではありま すけれども) 守っていく, それなくしては, 日本の環 境も, 日本の将来世代のいわば享受する環境の恵みも 守れないということであります。

それから，自然の対策ということも大きく変わりま した。従前の対策の考え方, 狙いは, 優れた自然の風 景地保護ということでありました。昔, 国立公園法と いうのがありまして，これはだいぶ古い法律で，昭和 6 年制定です。天然記念物のほうは大正時代ですか。 大変古い法律であります。観光地に外人さんを呼んで 外貨稼ぎしようという目的もありました。もちろん 自然保護運動もその頃はたくさんありましたから, 自 然保護ということも目標だったと思いますが, 外貨稼 ぎをしようというところもあったのです (笑)。で, アメリカのナショナルパークの制度に範をとって日本 でもつくろうということになったのが国立公園法の台 本であります。だから，風景の保護なのです。風景と いうのは,一つの総合的な指標ですから, いい風景だ なあと人間が感じるのは, やはりいい生態系をもって いる所かもしれません。そういう意味では, 国立公園 法は決して大間違いとはいいませんが，それは優れた 所だけを守るということでありました。

今後は，国土全体にわたって生物の多様性だとか, 人と自然とのふれあいを確保していくのだ，そして地
域の特性に応じて人と自然との間の共生を進めるとい うことです。

いくつか変わつたところのポイントがあるのです。 まずは, 生物の多様性ということは, 逆に言えば, 優 れた，傑出した，珍しいものだけを守るというのでは なくて，いろいろな人がいる，あるいは生物がいると いうこと自体を価值のあることだとみて，それを守っ ていくということですから，なかには珍しいのもいる けれどもあまり珍しくないのもいるのです。

たとえば，学校の頃を思い出してみれば，皆様方は 優等生だったのですから，よかったのかもしれません が,クラスのなかには，できない人もいれば，体育だ けできる人もいれば，音楽ができる人もいれば，絵の jまい人もいるわけでありますが，そういうものをみ んな大切にしていこうということです。そういうこと をしていかなければ,つまり，優れた自然だけを守っ ていたら「一将功成って万骨枯る」といいますか, そ ういうふうになってしまって, 結局は世の中は保なな いということもあるわけです。そういう反省をして, 変えていったということが一つあります。

もう一つは, 場所としてみても, 優れた自然という のは，人手のあまり入っていない海岸だとか，山奥な゙ とか, 島だとかというふうに思いますね。しかし，都 市の身近なありふれた自然というものも，それは優れ たものではないかもしれないけれども，やはりそれな りに自然なのだと考え守っていかなければいけないと いうことであります。あるいは，農村，山村，人手の 加わった自然もそうです。これもとても大切なものだ といっているわけです。だから，林業などでも，普通 は, 自然保護派の人は, 林業の対象になるような人工 林などはあまり価值をおかないわけでありますが, こ の環境基本法ならびに環境基本計画の世界は，そうい う持続的な, あるいは生産の対象となっているような, たとえば畑だとか森林などもそれはそれなりに自然と して 100 点ではないでしょうが, 当然, 環境政策の対 
象たり得るし，その限りの自然保護をしていかなけれ ばいけない。立派な自然ではないからどうでもいいと いうことではない，ということを言っているわけであ ります。

もう一つ, 環境負荷そのものを減らして, 自然の物 質循環を損なわないようにするというのも新しい方向 です。今までは污染物質の排出ということが問題だっ たわけですね。しかしそれだけではなくて，たとえば ゴミなどは別の污染物質とは言いがたいですね。ある いは, $\mathrm{CO}_{2}$ も，それは言葉の定義にもよると思いま すが, 環境庁自身は, これらも污染物質だとしますが, 普通の人の感じでは, 活染物質というふうにいわない よと思うかもしれません。しかし，環境負荷というふ うに捉えていこう，あるいは環境の中に物を捨てるだ けではなくて, 環境から物を取り出すほうも, これも いわば環境を寂しくするわけでありますので, 環境一 の負荷ということになるわけでありまして, もうちょ っと幅広い概念になるのです。この環境負荷, 法律的 には, 環境に与える悪影響であって, 環境保全の支障 になるようなおそれがあるものというふうに定義して います。少なくとも, 污染物質を環境中に出すという 行為だけが環境負荷ということではない，もっと幅広 い概念だというこは, ご理解いただきたいと思います。

そして, 公害と自然との垣根もだいぶ少なくなって きております。自然の中の物質循環を守っていこうと いうことでありまして，たとえば今までを言えば，水 の問題と言えば，水質污染ですね。それだけではなく て, 水辺の環境だとか, あるいは水の量そのもの, 川 の中に流れている水の量といったようなものも守って いかなければいけないというようなことになってくる わけです。自然の中の物質の循環が健全であるように していこうということであります。

\section{3. 環境基本計画の目標}

そういうことで, 大分ドラスチックな基本的な法制 度の変化があり，それを受けてもう少し分かり易く書 いたのが,この「基本計画」だというふうに思ってい ただけると有り難いと思うのです。

では，「基本計画」の中でどんなことをいっている のかということですが, 時間の関係で大変端折った説 明になると思いますので，後でお時間があれば，また このパンフレットを読んでいただきたいと思います。

まず，以下に説明する4つの目標を定名いるとい うことがポイントです。先ほど申し上げました理念み たいなことは, これは大体法律に書いてあるのですが, それをもうちょっと具体的に, こういうのを目指して
行動していこうという形に直していかないといけない わけでありまして, そういう意味で, 環境基本法を直 した目標というものを揭げています。

\section{1 地球を支えている物質の環境を大切に}

その1つは, 平たく言えば，「地球を支えているよ うな物質の循環を大切にする」ということです。具体 的に言いますと，生物が循環する形の社会を作ってや ろう, 環境への負荷の少ない循環型の社会, それが持 続的な発展が可能な社会だから，そういうものを作っ ていこうということであります。

今までは, 人の健康ということが第 1 プライオリテ イだった。それももちろん大事ですが，それだけに着 目して守ったり，対策をとったのでは，それすら長い 目で見ると守れないかもしれないということで，今は 物の世界の健康といいますかね, 自然の世界の, 物質 的な意味での健康というものを大切にしていこうとい うことで，この物質の循環を損ねないように，という ことをいっているわけです。

たとえば，そういう問題としては，もちろん $\mathrm{CO}_{2}$ もそうですし，富栄養化というような問題もそうです ね。それから水もそうです。どんどん上流でとってき て，ジャブジャブ使って捨てちゃうというようなこと で果たしていいのかどうか, そういう問題がこの問題

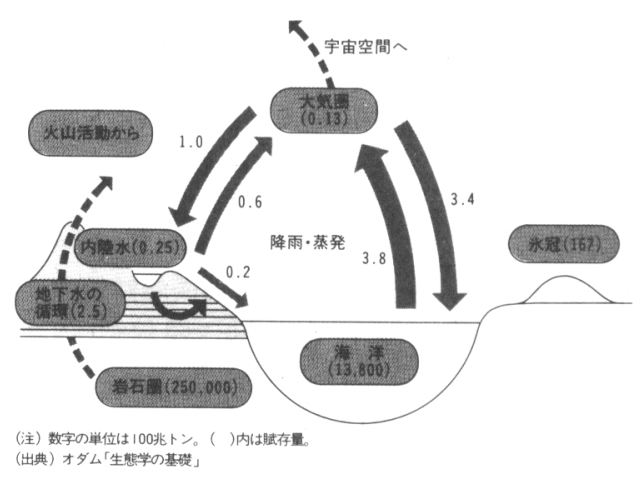

図 7 水の循環

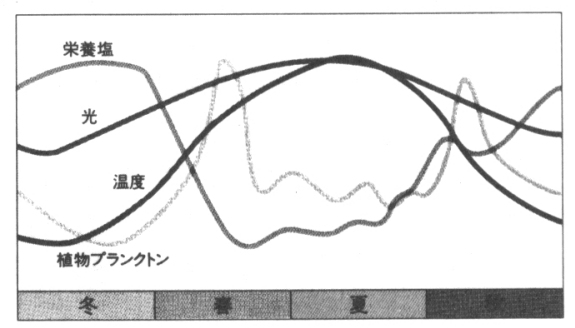

（出典）オダム「生態学の基砹」

図 8 温带地域の池や湖の植物プランクトンの消長 


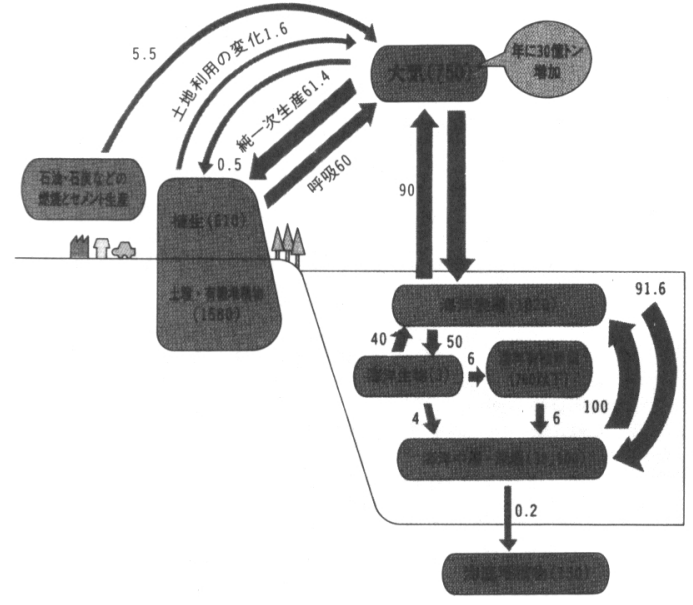

(注) 数字の単位は炭素換算10䪰トン( 1 年当た

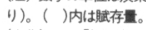

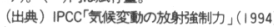

図 9 炭素の循環

\section{です (図 7,8,9)。}

3.2 自然と人間とが共に生きる関係を築く

2 番目の目標が, 人と自然とが共生できるような, 共に生きられる環境を作ろうと，こういうことであり ます。

人間の生存, 生活は, 自然からの恵みに支えられて 成り立っています。例えば食料を考えてみましょう。 生態系では図 10 のように生産者である植物が太陽工 ネルギーによって有機物を生産し, それを草食動物が 食べ，草食動物を肉食動物が食べるというピラミッド が成り立っています。このピラミッドは, 階層が上に いくほど生存できる数が少なくなります。人間は他の 動物とともに植物の生産した有機物を消費しています が, 人類が消費している割合として図 11 のような試 算があります。人間一人が生きるためには, 大変な量

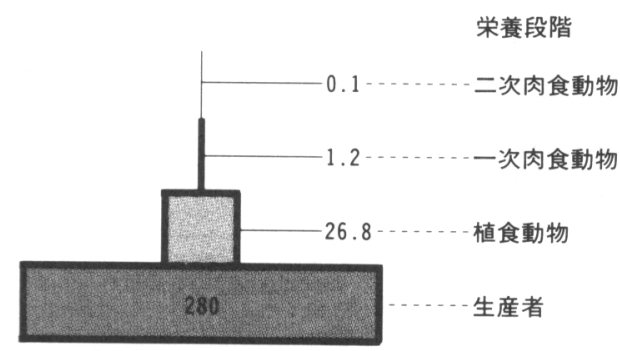

（注）栄養段階別の生産力をmg/m²/日て示した。燐のとりこみ速度から推定。 二次肉食動物は、植食動物及び一次肉食動物の両方を捕食する肉食動物の一 部。栄養に乏しい浅い実験池での事例。 (出典) ホイタッカー「生態学概説」

図 10 生物群集ピラミッドの例

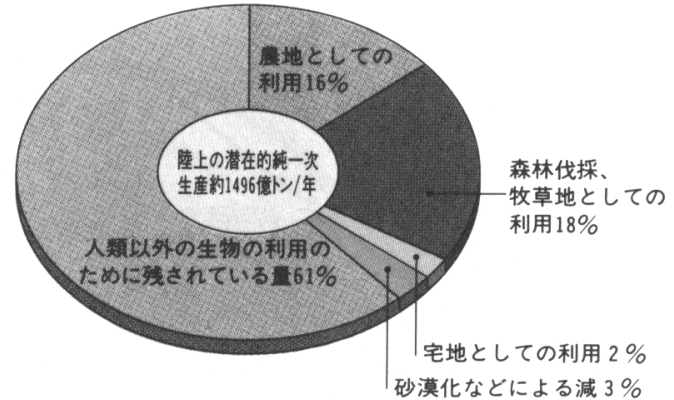

（注）純一次生産とは、太陽エネルギーを植物か固定して得た有機物量から、植物自 身が消費するものを差し引いた有機物量。中央の数値は、人間の活動がなかったと した場合に得られるであろう純一次生産量を示す。人類はこれらのうちの $39 \%$ を農 地・牧草地への転用や農林産品などの形て利用している。

(出典) 平成 4 年版噮境白書。原資料は国際自然保護連合「新世界環境保全戦略」

図 11 生物の活動に占める人類の活動の割合

の生物の恵みが必要なのです。

私なちが呼吸する空気も, 飲む水も, 自然の恵みで す。森林などの緑は酸素を供給したり，二酸化炭素を 固定したりして，人類生存の基盤となる大気の状態を 保つことに欠かせない役割を果たしています。さらに， 水の蒸発を通して気温を安定させたり, 大気や水の中 の污れた物質をきれいにするといった能力ももってい ます。

このような物質的な面だけではありません。自然が もたらす恵みは精神的な面でも大きなものです。例え ば素晴らしい自然に接したときに感じるインスピレー ションは，私なちに精神的豊かさを与えてくれますし， 自然の緑は人々に安らぎを与え, 精神の安定に貢献し ます（図 12）。さらには自然は科学の情報源でもあり ます。

白然の生態系は, 植物, 動物, 微生物とそれらを取 り巻く大気，水，土などの無機的な要素といったさま ざまな要素を密接にかかわりあった複雑・精妙なシス テムを形成しています。私たちは，さまざまな面から 私なちを支える自然からの恵みをいつまでも受け続け ることができるよう，自然に譲ることを含め，自然を 賢く上手に利用することを通して，健全な状態を保っ ている生態系を維持したり，失われた場所においては 回復しなりして，人間が多様な自然・生物と共に生き る地球を確保することが重要なのです。

\section{3 社会の構成員すべてが参加する}

3 番目の目標はこれはいわば手段的な目標といいま すかね，物の循環を損ねないように，あるいは人と自 然との共生を図っていくというようなことに対して， いわばそれを目指した手段なのですが, 社会の構成員 


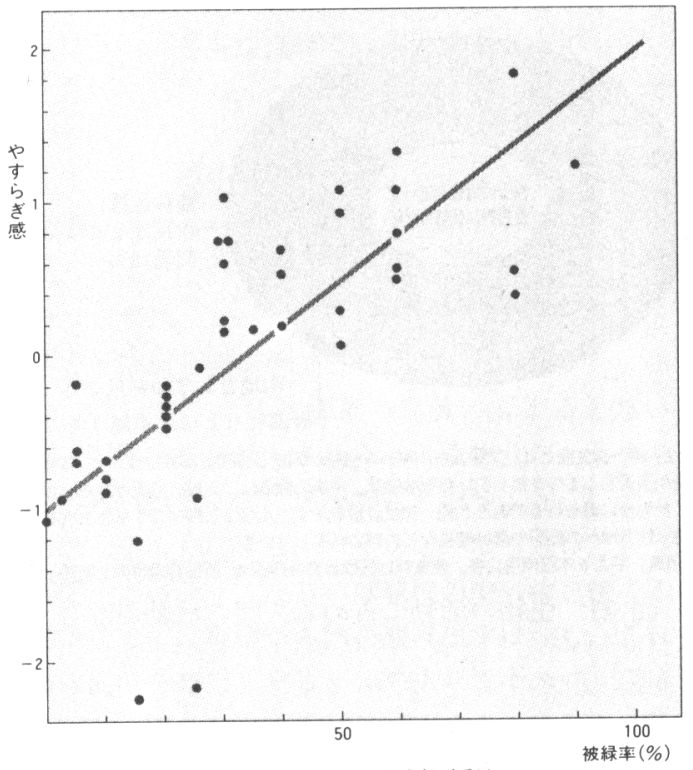

(注)風景の中の緑の比率と被験者が受け る「やすらぎ感」(複数の形容詞対から因子 分析により導かれた評価軸)との相関。 (出典) 品田裹著「ヒトと緑の空間」

図 12 やすらぎ感と被緑率

のすべてが公平な役割分担のもとで参加していくとい うものが 3 番目の目標になっているわけであります。 この 3 番目の目標というのは, 大変ユニークです。 政府の計画で「参加自体が目標」というのもおもしろ い話であります。童謡でいえば,「良い子の住んでい る良い町は, 楽しい, 楽しい歌の町」だといいます。 いろいろなことをいわれていますが，やはり良い子が 住んでいてこそいい町なのです。単に物的に人と自然 が共生するとか，あるいは物がちゃんと循環している ということだけではなくて, 社会の成員の方々が, み んな，それぞれに環境保全の役割を果たしているとい うことが大事なのだ，ということなのであります。

例えば，環境对策には費用がかかりますが，環境を 污染するような活動をする人が污染のために社会に損 失をツケ回ししないよう，污染を防ぐ費用をまずもつ て負担するということをルールにすれば，皆ができる だけ環境を污さないように努力するようになります。 このルールを「污染者負担の原則」といいます。

図13の水道料金の内訳を見てください。水の使用 のための支払われる抄金は，鉄やセメントでできてい る水道施設の建設費や, 施設を運転するための電気代, 薬品代，人件費などのさまざまな費用に充てられます。

この過程で環境負荷が生じます。図 14 は, こうし た間接的な環境負荷も含好, 産業別に二酸化炭素排
出量を計算したものです。余り二酸化炭素を出してい ないと思っている会社も, 実は, 二酸化炭素を沢山出 している会社のお㓌をこうむつているのです。間接的 な環境への負荷についても, 負荷が発生する段階ごと に対策を講じれば，それが製品などの価格に反映され て, 製品を使う人が環境保全のための負担をすること になるのです。これが市場メカニズムの利点を活かし

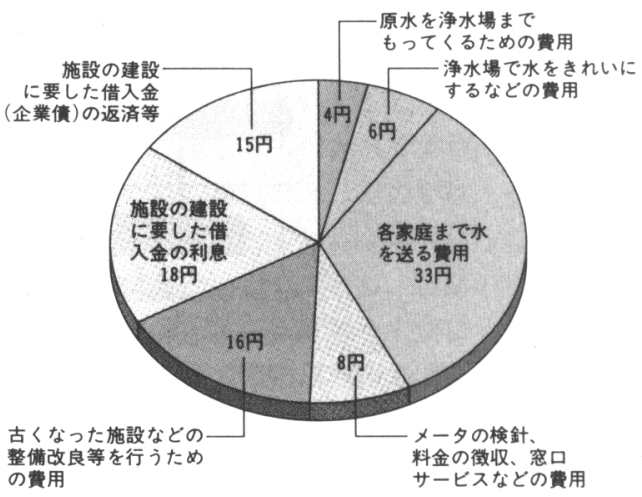

(出典) 平成 5 年版瞏境白書。原図は、東京都水道局「水道サービス手帳資料編」 (平成 3 年度)。

図 13 水道料金 100 円の使い方（平成元年度）

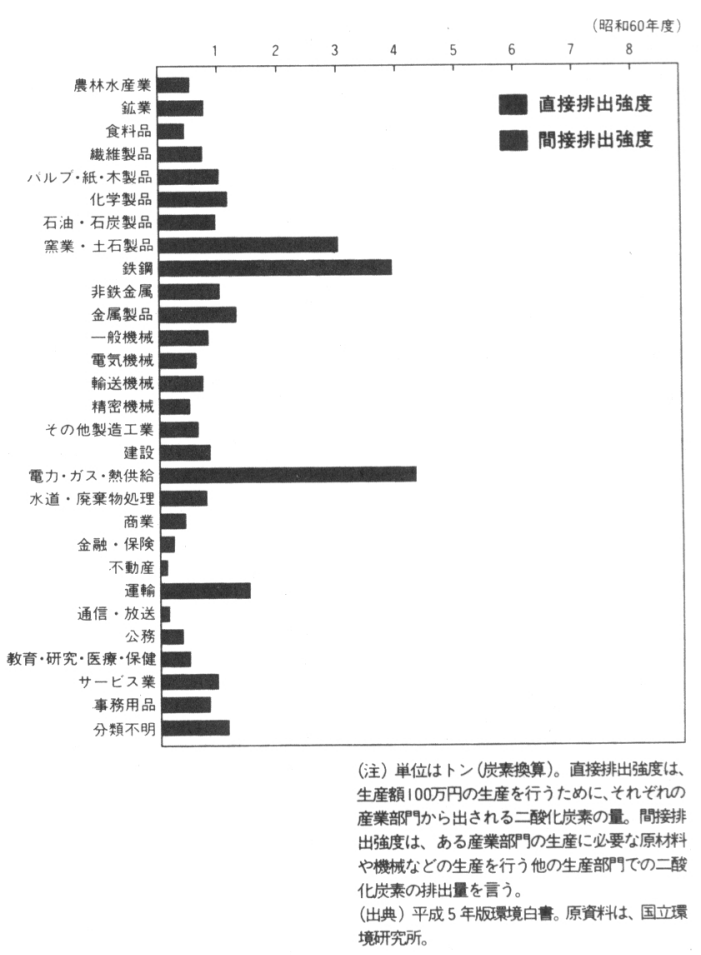

図 14 産業連関分析による部門別二酸化炭素排出濃 度 (昭和 60 年度) 


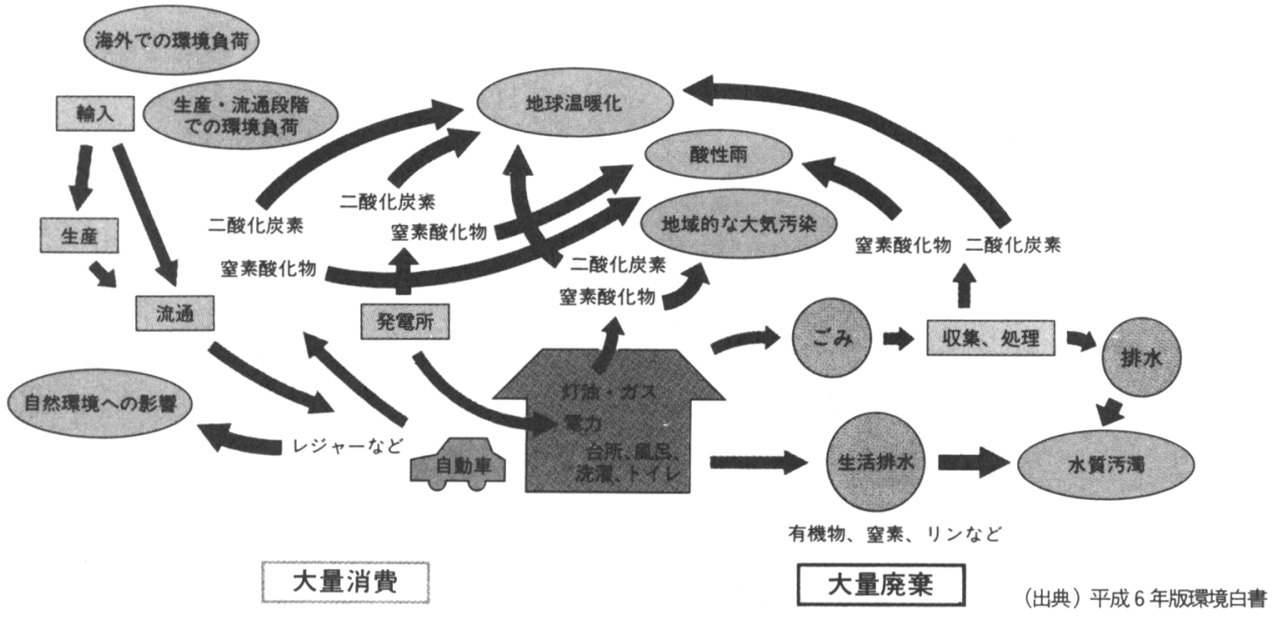

図 15 ライフスタイルと環境負荷

た環境保全のルールです。

私たちの日常生活は, 図 15 に示すように, さまざ まな形で環境への負荷を与えています。環境を守るた めには，私たち一人ひとりがこのことをしっかりと認 識し, 自らのライフスタイルを見直し, 消費者主権を 発揮する努力をしていくことが肝腎です。

このように社会を構成するすべての主体が, 自分の 役割をしつかりと果たすことによって初めて，物質環 境を大切にする社会, 自然と人間とが共生する社会を 築いていくことができるのです。

\section{4 国際的な視野で努力}

それから「国際的な視野でやっていく」。これも当 然ですね。日本のことだけを，日本の都合だけを考え ていくということでは駄目ですよと，譲るべきものが あればやはり譲るし。協力というようなことをしなが らやっていく，あるいは人様のために考えてやる。外 国へ行って ODA でも環境 ODA をするとか, ボラン ティア活動をするとかというような，これは，直接に は日本の利益ではないですが，そういうことを考えて いるということでありまして，この国際的な視野でや つていくというのを 4 つ目の目標にしたわけです。

我が国の果たすべき役割を考えてみますと，図 16 のとおり，世界の人口は急激に伸びていて，特に開発 途上国で今後とも伸びていくと予測されています。ま た一人当たりエネルギー消費も，図 17 のように伸び てきています。このように人類の経済活動が巨大化し てきている結果, 地球環境に及ぼす影響も甚大なもの になってきております。

日本は世界の中で大きな位置を占めています。図 18 に示すように，世界で生産される資源のかなりの

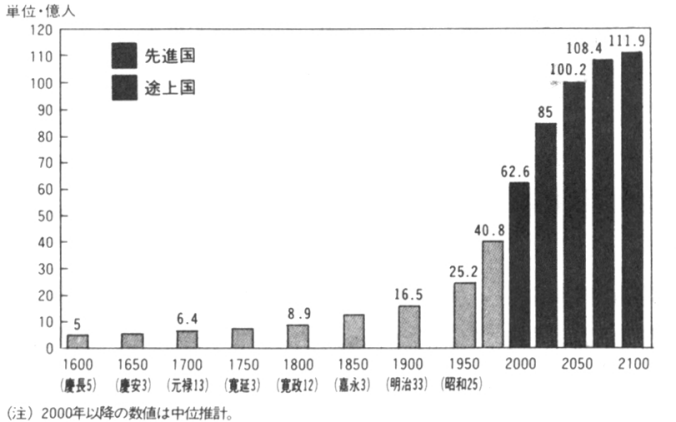

注）2000年以降の数值は中位推䄈。

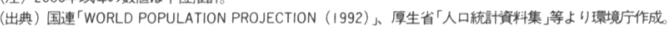

図 16 世界人口の推移と予測

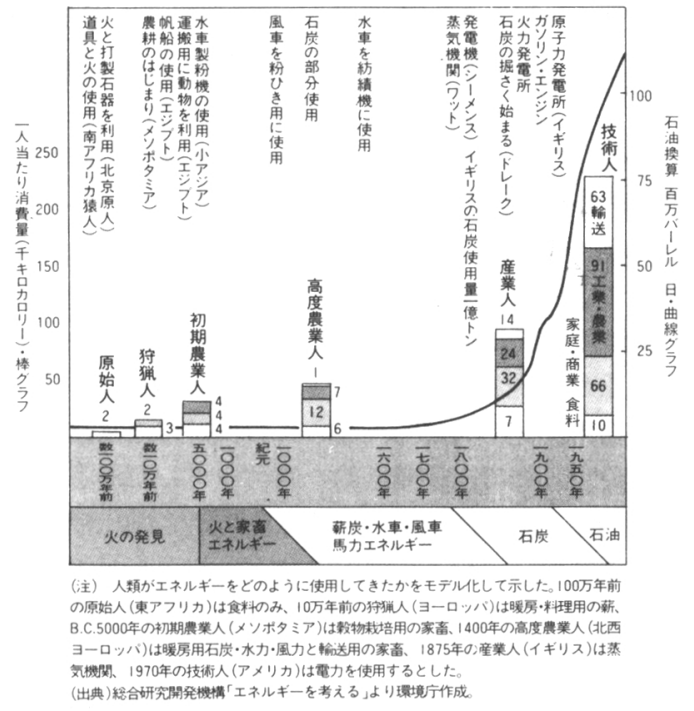

図 17 人類のエネルギーとのかかわり 
囷油輸入量 (平成元年)

日本の輸入 178.343 千トン $(6.0 \%)$

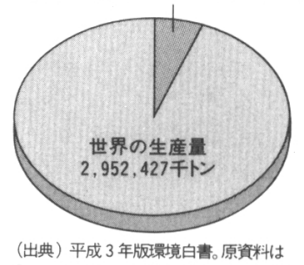

（出典）平成 3 年版摆境白書。原資料は

国内総生産(平成3 年)

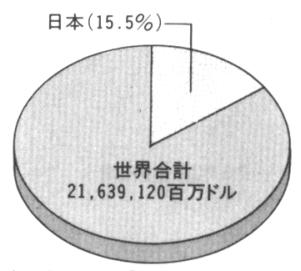

(出典)世界銀行「WORLD DEVELOPMENT REPORT 1993」より環境庁作成。
目材輸入量 (平成元年)

日本の輸入 $60,849 千 m^{3}(26.3 \%)$

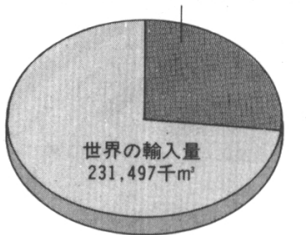

(出典) 平成 3 年版瑀境白書。原資料は FAO貿易年鑑、同林産統計年鑑。

二酸化炭素排出量 (平成 3 年)

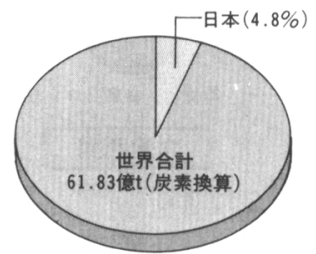

(出典)オークリッジ国立研究所二酸化宸素 情報解析センタ一推計値より環境竞作成

図 18 人類の活動に占めるわが国の割合

部分を日本が輸入し，その結果生み出される経済生産 の量（国内総生産）は世界の $15 \%$ 強を占めています。 また，二酸化炭素排出量などの環境への負荷も，大き な部分を占めています。

さらに，日本はこれまでの公害対策技術などの大き な蓄積を持っています。我が国はここうし国際的な 地位と経験，能力などにふさわしい国際的な環境保全 の取組を進めていくことが求められています。

\section{4.これからの取組}

ただいま申し上げたのは大変抽象的です。では，ど ういうふうなことになったら循環が進んだのか，ある いはどういうふうになったら，共生が進んだのか，自 然と共生できるようになったのか，あるいは国際的な 取り組みがどれだけ進んだのかわからない，というこ とがありまして，これは大変厳しく批判をされ，新聞 の社説でも吒かれました。政府の計画としては大変珍 しい計画であり，憲議会で作っていたわけですが，そ の番議会が中間的なとりまとめというのを克明にし， それを全部オープンにし，さらに国民からの意見を求 めたということで，手続き的なユニークさがあるので す。その後, 今回, 経済計画なども経済企画庁で作ら れていますが，これも中間とりまとめを公表して国民 の意見を聞くというようなやり方になっています。

昔は，国民の意見を聞くといっても，好きなことを 言ってくださいと, 審議会なり役所のほうは, 何も手 の内を見せないで，次期計画をどう思うか，どんなこ

とを希望しますかってなことを適当に聞いて，あとは 「よきにはからえ」とやってきたともいえるわけであ りますけれども，いまはそうではないですね。大体政 府としてはこんなふうに思うけれども, みなさん, ど うでしょうかということで，手の内を開かして意見を 聞くようになっているわけであります。この「環境基 本計画」は，そういう計画であったわけでありまして， 去年の夏の 7 月頃に, その中間報告ということで, ほ とんど最終案と同じようなボリュームのものを発表し ました。

話は元に戻りますが，しかし，そのときに厳しく批 判を受けものの第 1 点は, この目標はいいけれど抽象 的だから，これを数量的な指標で示せないかというこ とであります。

いろいろなものがあると思うのですが，たとえば， 循環ということですと, 図 19〜23を見ていただきま すと，いろいろな指標があります。こういうグラフと いうのは，みんなそれなりに何か意味があって，そう いう意味でいえば指標なのでしょう。それを，しかし 目標の座にまで祭り上げるかどうかというのは, 今度 は政策判断といいますか, ひとつの決めの問題, 意志 決定の問題ですから選びとって考えなければいけない。

これからの課題ですが，たとえば，この「循環」と いうことでいうと, 日本全体のマテリアル・バランス というのは, 図19の通りになっているのです。我が 国は資源を外国から 7 億卜ン持ってきて，それから国 内の資源の 14 億卜ンを使う。それは, 農産物もあれば, 木材もあれば，重さからいってすごく多いのは，土砂 とか砂利, コンクリートに混ぜる砂利とか, そういう のがあります。そしてリサイクルされているのが大体 2 億トンあり, 物質としては, 大体 23 億卜ンを年々 使っているということです。それから不要物である廃 葉物が，たとえば産廃では 2.6 億卜ンとか，あるいは 一般廃萧物でいいますと 5,000 万トンとかいうふうに 出てくるというようになっているわけです。この資源 投入量に対するところの廃棄物排出量の割合を見てみ ると,だんだん効率のいい経済になっているのではな くて, 印象としては高付加価値化していて, だんだん 原材料から離れた生活をしているのかなというふうに 思うわけでありますが，今まではどちらかというと， 実は無駄遣いが進んだ経済だったのです。

しかしバブルが弾けて以来の不況で, やはり少し物 を大切にしなけ机ばというようなこともあったのかも しれませんが，今のところ，自然投入量に対するゴミ の出方というのは頭打ちになっています。本当をいえ ば、これを下げていかないといけないのです。もっと 


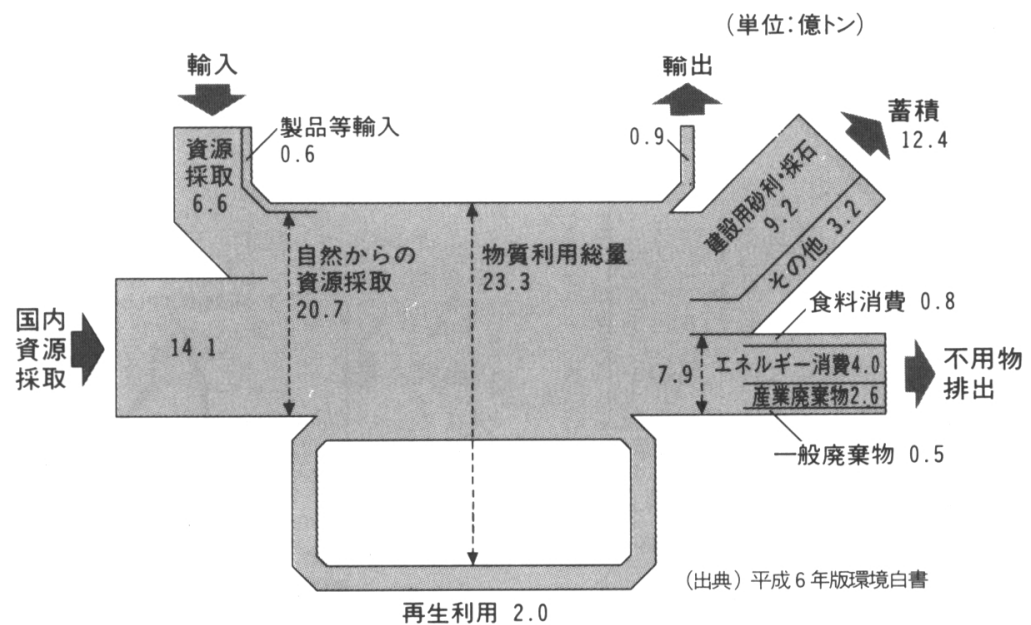

図 19 我が国のマテリアル・バランス（物質収支）(平成 4 年度)

無駄なく使う。よく，お金持ちになると，物の大切さ よりも心の豊かさといいますよね。だから，物はあま り使わなくなるようになっていいのだけれど，物の大 切さよりも心の豊かさといって，物をどんどんジャブ ジャブ使い捨てにして，いくら物を使っても満足しな いということになってしまってはいけないわけです。

ですから，物質利用総量に対する再生利用量だとか, あるいは資源投入量に対するところの廃棄物のアウト プットとかというのは，いわば循環が進んでいるかど うかのひとつの指標になります。数字でどういう指標 になるかわかりませんが，今後，いずれにしても，な だ単なる作文の目標ではなく，みんなの努力をそこで 結び合わせてどの政策がどれだけ一番利くかとかとい うようなことについて数学的な目標を立てることが大 事でありますので，政府としては，この目標を早急に 数量的な指標にしていくような作業をすることになっ ているわけです。

そうするということをこの環境基本計画の中の一部 分として，閣議決定をしているのです。

\section{1 大気環境を守る}

以上 4 つの目標ごとのいくつかの具体的な対策の内, たとえば，地球温暖化のことについて言いますと， 「地球温暖化防止行動計画」というのが定められてお ります。それをちゃんとやっていくことは，既成の方 針ですが，それだけではなくて，2000 年以降のこと についても若干触れておりまして，2000 年以降のこ とを考えれば，今の努力では明らかに不十分ですから， もっと積極的にやらなければいけないというようなこ とも書いております。地球温暖化防止行動計画につい ては実績といったものを踏まえて，手直しをしながら
やっていかなければいけないというようなことも書い ております。これらは，この基本計画では，新しく定 めたところでありますし，オゾン層の保護ということ についてもかなり書いております。

それから広域的な大気污染だとか, 窒素酸化物対策 なども，大昔からやってきてレールの引かれている話 ではありますが, こういうことについても，さらに現 在の自動車規制もさらにグレードアップをする必要が あるのではないかというようなことも書いております。 一番のポイントとして, 多様な有害物質対策をもっと やっていかなければいけないということをかなり強く 書いております。

この計画自身は，実は，21 世紀半ばまでの環境の 状況，あるいは人類の活動というものを一応頭に入れ， とりあえず人間の知恵を及ぶところとしては，21 世 紀の初頭までの計画ということで書いてあるものです。 それも，おそらく当然そんなに長い夕イムスパン，つ まり，10 年，15 年の対策の方針を書くというのも， また知恵の及ばないところがありますから，おそらく 5,6 年後には見直しをしようと考えているわけです。 そういったタイムスパンの中で, この計画は動いてい るわけであります。

そういうタイムスパンの中で見ますと, 大気污染対 策というものはかなりレールが引かれていることであ りますから, 基本計画の方でつけ加えたことはあまり ありません。それをきっちりと引き継いでいるという か，位置づけたということだろうと思います。

\section{2 水や土を守る}

他方，水や土ということになりますと若干变えてお りまして, たとえば水の循環ということはやはり大事 


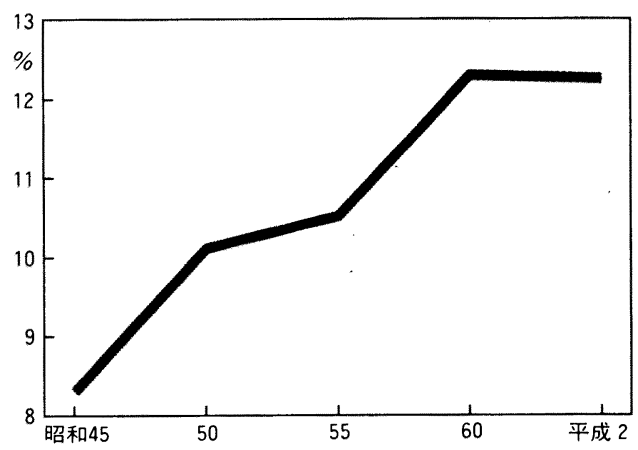

図 20 資源投入量に対する廃棄物排出量の割合の推 移

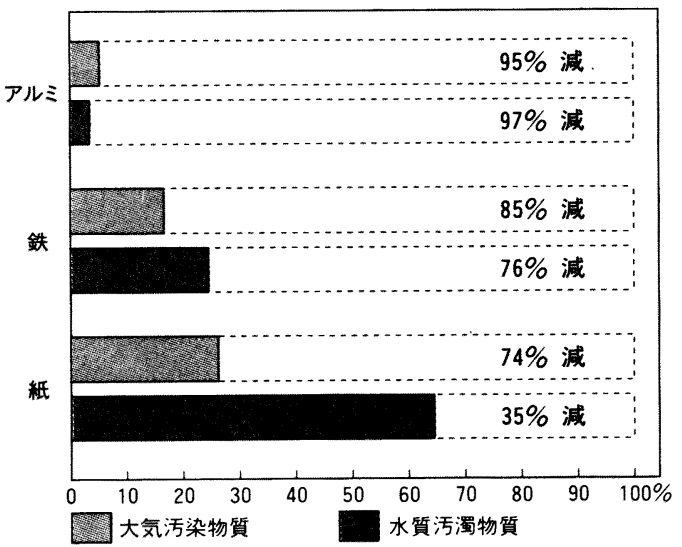

（出典）レスター・ブラウン「地球白書|987年版」より環境庁作成。

図 21 再生原料から作った場合の工場から出される 各種污染物質の減少

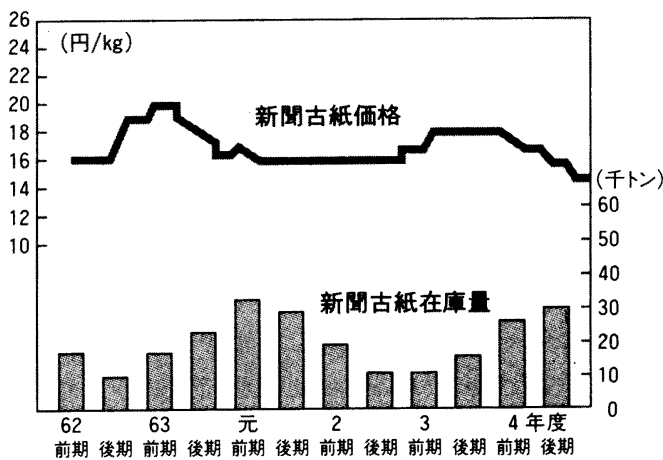

（注）古紙価格は、東京地区近郊メ一力一工場符価格。古紙在庫置は、関 東地区直納問屋大手 32 社の在庫量。再生紙の絛要か隇ると、古紙が余つ て価格も下がってしまいます。

(出典) 平成 5 年版摆境白意。原図は財)古紙再生促進センター、日本再生 餈源共同組合連合会。

図 22 古紙価格と在庫量の推移

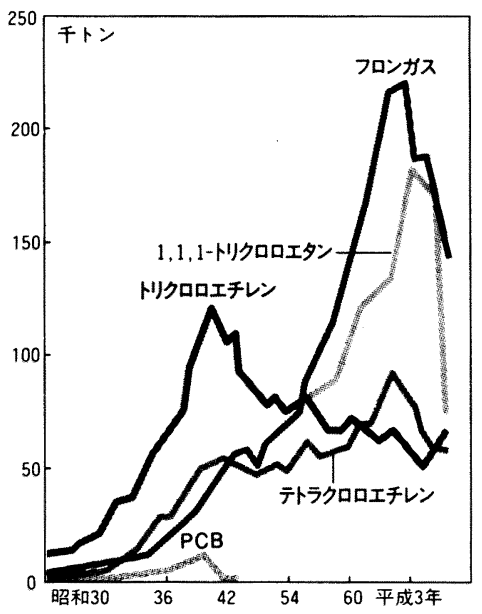

（出典）化学工業珫計年報等から㻴境庁作成

図 23 さまざまな化学物質の生産量

であります。今までは水質污濁・水の污れということ だったわけですが，それだけではなくて，水が豊かな こと, 水量だとか, 水辺環境といったものを含めた水 環境という概念を出して，それの健全性を高めていく ということをいっております。そういう意味ではだい ぶ政策が変わってくるということがいえると思います。

土についても土壤環境ということで，今年の環境白 書などにも，かなり熱心に書いております。土が大き な重要な働きをしていることも書いております。

\section{3 廃棄物や化学物質などの対策}

ゴミのところは，「廃萧物のない社会へ」というこ とで，かなり徽底して書いております。ここも国民の 意見の中で大変意見の多かったところで，ほとんど全 面的に書き換えておりますが，その中で廃棄物対策の 政策的なプライオリテイをはつきりと書いてあります。 実は廃棄物の対策の方針というのは閣議決定などは今 までしたことないのです。皆様が今まで見られたのは， たとえば，何省かの審議会の何かの専門委員会のちょ つとした報告であったりとかで，全然政府としてエン ドースしたものではなかったのです。しかし，今回は はっきり政府としての大方針として閣議決定した方針 を書いたという点が，まず画期的であります。

何をいっているのかということですが, この廃衰物 のない社会を作っていくために，まず第 1 には，廃衰 物そのものを産まないというのが大事なのだ，これは 第 1 プライオリティなのだということをいっておりま す。今度の包装廃亲物法でもいろいろもめましたが, やはりこのへんの精神がちゃんと入っているかどうか ということが大事だったわけです。 
次に，使えるものはそのまま繰り返し使うという 「リユーズ」という課題です。これを第 2 のプライオ リティに，そして第3がリサイクルであり，使われな くなったものを四仪して，原材料として利用するとい う意味でのリサイクルを行なう。最後にどうしても駄 日であれば，その処理，いわゆる烧却，埋め立てとい う流れにしていくというプライオリティをはっきりつ けたというようなところも新しいところであります。

さらに，创装廃集物法の話は，もちろん基本計画の なかにも㫷いてありますし，この開題以外のこともい ろいろ書いてあります。今後の政策を占うトでは，非 常に情報洒值があると思います。

それから，化兴物質の環境りスク対策なども大変重 要なところです。「環境りスク」という言葉の概念も， まだ日本の社会には馴染みにくいところもあるかと思 いますが，やはり大人の議論としては，環境りスクを ゼロにすることはできないわけでありますから，どう いうふうにしていくのかということを考えていかなけ ればいけないわけです。そのへんの開題もはっきり取 りトトげてきております。

\section{4 健全な生態系を保ち自然と共生する取組}

自然保護のことでけいますと, 先ほども申し、げま したように，一番大きな変化は優れた问然だけを守る という発想から離れて, 川地の门然のある所, 果地の 所も平地の所も淠落地域も，それなりに，それぞれ環 境・回然を保護をしていくというようなこと，また生 物の多様性というようなものを行っていくというよう なことも大执ということも其いてあります。アメ二 ティなども草いてございます。

\section{5 皆が参加する取組}

全員参加のこと，これもやはり環境页侕が䦌題にな

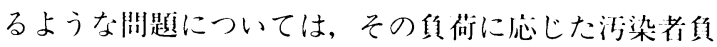
担の原則というのが大原則だということをかなり強く

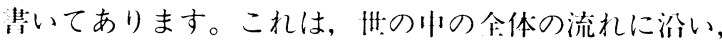
由记的な社会をつくっていこう，みんな目责低とい うものをやはり䈌しく閌う形になっています。なんで

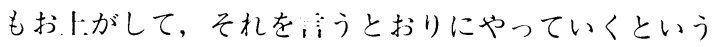
社会ではない。そういうのは非效䔞だということが, はっきりしてきているわけですから，向けした社会， 扎し賁任をちゃんととる社会ということになりますと， やはり活染都傎扠の原則というのが大原則だというこ とをかなり強くここで其いてあります。逆にいえば, 事業者のおあるいは役所にとってもそうですが, 責任 が重いということになってくると思います。しかし， そういう责任を果なそうとするとややはりきちっとし た情報というものがないといけない。その情報を提供
するのも現在, 議論されているところです。環境のこ とだけ公開だというわけにはいかなかったので書いて いませんが，しかしその言葉を使わないで斉む限りで, かなり書き込んでいる。事実上, 公開すれすれの書き 方です。たとえば，様々なニーズに応じた情報の提供 をするということはある程度考えてやらなければいけ ないことになるわけでありますから, 大変です。

そういうことで, 日本は特に情報公開が遅れている というのは，アメリカなども知っていて，それが日本 の企業を守っているのではないかという批判ですらあ るわけで, 遅かれ早かれ, 環境情報についていえば, 外国並の公開ということは避けて通れなくなると私ど もとしては思っております。それから，自主的な活動 を支援するためにいろいろなことをしていくというこ とがあります。

\section{5. 率先実行計画}

国も当然事業者としてやっていく。自主的, 積極的 に対策をとる。つまり，ものの考え方として，全部規 制でやっていくというのではなくて, 自主的, 積極的 にやっていくことが出来るようにしていかなければい けない。それが参加の社会ということだと思うのです。 まずは自主的，積極的にできるものならやってみよう と考えております。

そういう意味で言いますと, 国自身も, 自主的・積 極的にやらなければいけないということを 6 月 13 日 の閣議で決定をさせていただきましたのがお手元に配 つた小さなパンフレットです。国の事業者，消費者と しての環境保全に向けた取り組みの率先実行のための 行動計画というものです。

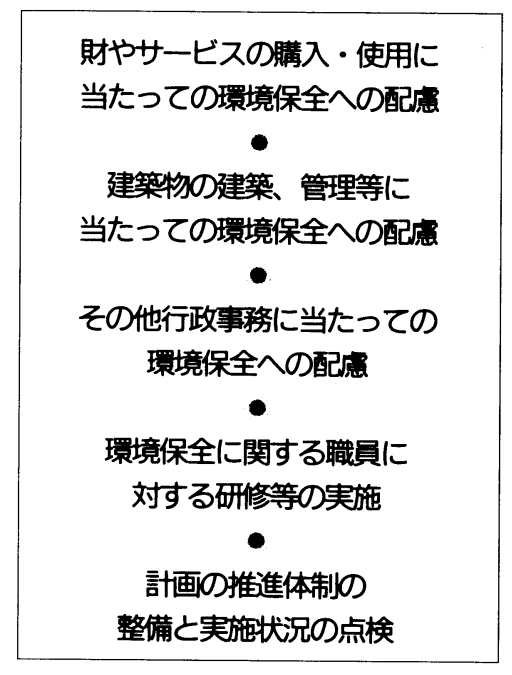

図 24 率先実行計画の構成 
これを説明させていただきますと，図24に5つの 分野, 「率先実行計画の構成」ということを書いてお ります。財やサービスの購入，使用にあたっての環境 保全への配虑，それから建築物の建築管理等に当たつ ての環境保全の配虑，その他の一般な行政事務に当た っての環境保全の配虑, 環境保全に関する職員に対す る研修の実施と, それから, この計画全体の推進体制, といったものがエレメントになって構成されておりま して，全体で，閣議決定ベースは 31 項目ぐらい，そ のあとマニュアル的な局長レベルの申し合せをしてお りまして、これが 130 項目ぐらいあります。.1つは計 画の進行管理ですが，それを除いた 4 つの分野という のは何かといいますと, 最初の分野は物がもう出来合 いのものとしてあって，それを買ってくる，選び方み たいなものが大事だということです。たとえば，皆様 方の業界でいえば，なるべく再生紙を買うとか，バー ジンパルプの少ないものを買ってくるよと，こういう ことですね。また，たとえばエネルギー消費の少ない $\mathrm{OA}$ 機器を買いますといったことです。

図 15 の 2 番目の建築物の建築管理というのは, 必 ずしも建築物だけではないのですが, 敷地の緑地の問 題とかいろいろ書いてあります。要するに，これは出 来合いのものではなくて自分たちで注文して作るもの， この典型は建築物です。こういうものについての環境 配慮は，これは自由に設計するわけですからいろいろ なことができるわけでありまして，太陽光を利用する だとか，パッシブ・ソーラーとか，いろいろあります が，それを使っていくというようなことが 2 番目であ ります。

3 番目は何かというと，そういった作ったものとか, 買ってきたものの使い方です。ソフトウエアを書いた のが 3 番目です。

そして 4 番目の職員の研修などが書いてあるのは, 要するに，それを今度ソフトウエアを実施するところ

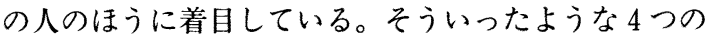
構造になっています。

図 25 に掲げているものが主に数字的な目標の入っ ているものを中心に何項目か選んであります。数字的 な目標が入っているのは 11 項目ほどあります。説明 は省略をさせていただきますが，中央政府は，統計上， GDPでいうと大体 2.2 パーセントぐらい占める。あと， 地方政府も合わせますと約 10 パーセント弱のシェア を占めているわけで, 政府部門というのは最大の企業 です。中央政府だけでも GDP 統計上，数字が出るぐ らいの大きさですから，やはり最大の企業というふう にいうことができると思いますが，その企業のいわば，

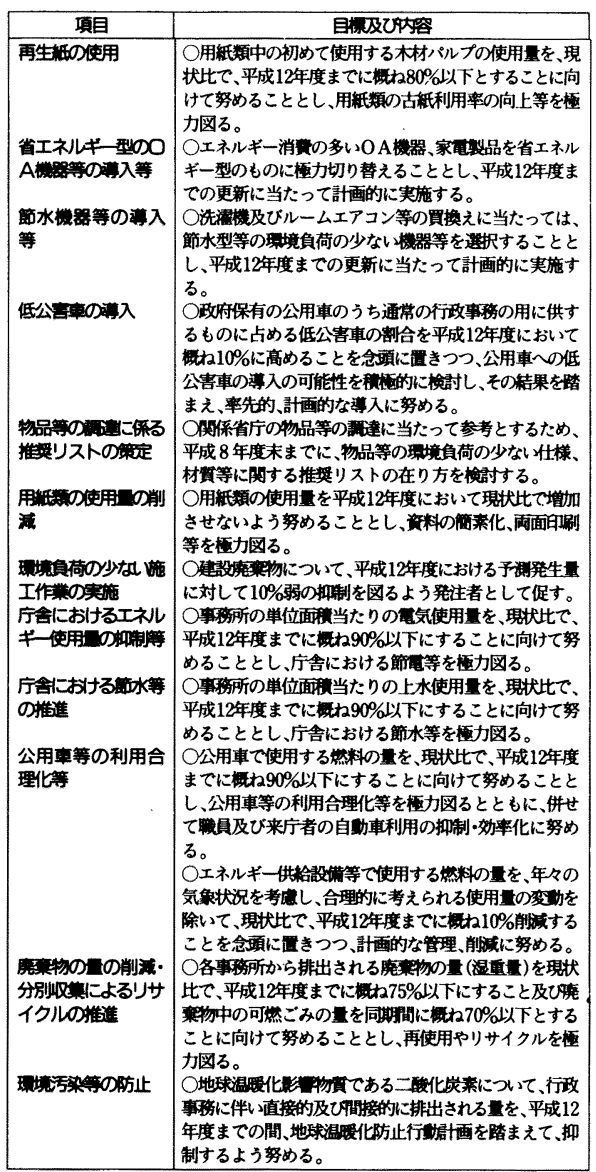

図 25 主な取組の目標及び内容

もちろん政府自身，政府しかできないことはたくさん ありますので，それはそれでやっていきます。アメリ カでも法制自身の改革をマルチメディアで考えて，モ グラ吒きではない方法でやっていこうという動きがあ ることは申し上げたとおり，こうしたことをやってい きますが，これに加えて，企業としてもやっていくと いうことです。また，これからの環境对策というのは， 世界中で大きい市場があるということもあります。ア メリカ政府も，実は，この率先実行というのをやって いるのですが，明らかに連邦政府が新しい需要を作る ことによって技術開発を引っ張っていこうということ なのです。エコ産業というのは，世界中でこれから需 要として出てくるのでありますが， 3000 億ドルぐら いの市場規模が既にあるとアメリカでもいっておりま す。日本でいうところの 30 兆円，そういう市場規模 がある。しかも他の平均的な産業の成長率よりも早く 伸びています。

製造工程の改善や経費を節約したり，新しいビジネ 
スを作ったり，技術を作ったりというのは人に言われ たからしょうがないとしてやるというょうな受け身の 発想というのではあまり産むものが少ない。ぜU自分 の問題として取り組まれることが，やはり厳しい競争 の社会ですから。かえって競争を有利につくっていく， リードしていく道になるのではないかなというふうに 思うわけであります。

たとえばケナフのほうがいいんじやないかとかいう 世間の声だってありますよね。そういうときに，やは りそればっかりじやないと，収穫量からすれば，森林 のほうが，たとえば炭素固定量が大きいのだとかなん かいっているだけではなくて，もっと強く，実際に訴 えていく，あるいは単一，単相林で植林ばかりした林 じやだめじゃないかといわれたら，もっと違う技術開 発もしてみせるとか, やはりそういう批判というのは, しかし逆にいえば，新しいビジネスの種を示している のですから，逃げではなく攻勢防御ならびにそういっ た批判を呼ばない技術開発ということをしていくこと が，これからの業界では，一つの生き方かなあという 気がするわけであります。紙というのは，これはもう 文明の利器でありまして，なくなるわけはないもので ありますが，これからやるべきことは大変多いのでは ないかと思っている次第であります。ぜひ，こういっ た機会にも，いろいろな他のご講演のヒント等々あろ うと思いますが，私は素人でございますから全般的な 話しかできませんけれども，そういうところからヒン 卜を得て新しいことにチャレンジをしていっていただ けたらと思うわけです。

あと，環境税の話とか，アセスメントの話とか，国 際的な取り組みの話とか，いろいろ書いてありますが, 資料を読んでいただければわかるところでございます

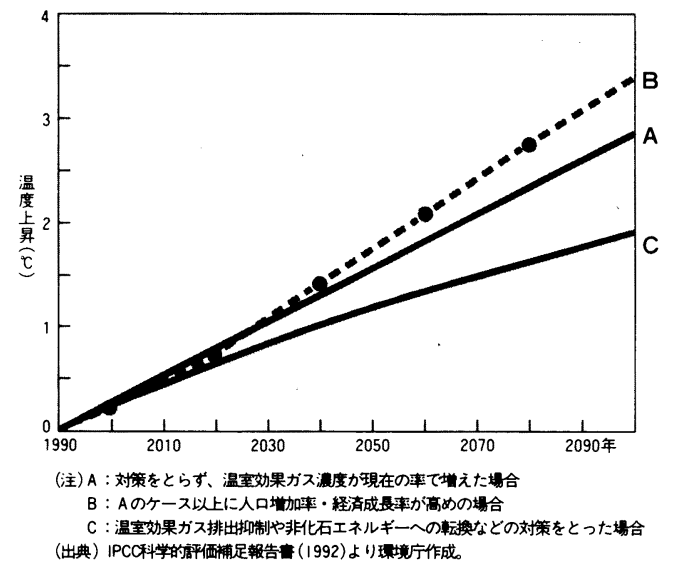

図 26 地球の平均気温の将来予測

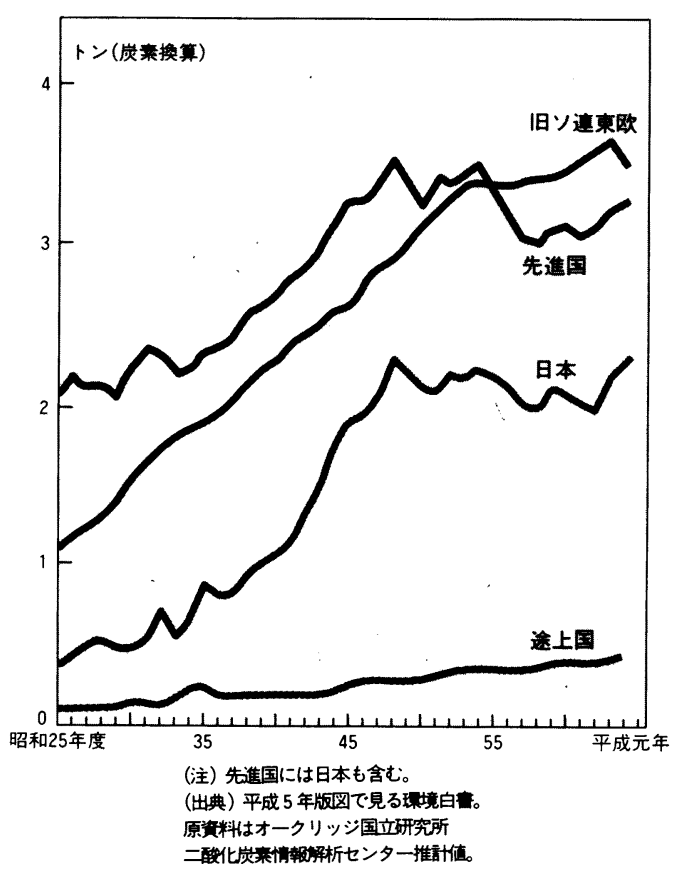

図 27 一人当たり二酸化炭素排出量の推移（昭和 25 年から平成元年)

から省略をさせていただきます（図 26，27）。とりあ えず，私からの話は以上にさせていただきます。もし ご質問などがあればお答えをいたしまして，いま申し 上げましたことのいたらなかったところを補っていき たいと思います。どうもとりあえずはありがとうござ いました (拍手)。

\section{$<$ 質疑応答 $>$}

司会 せっかくの機会ですので，ぜひ質問をお願いい たします。

質問（A 氏）大変分かり易いご説明をありがとうご ざいました。私は，環境の一応の専門家の端くれです ので，このパンフレットは何回も見る機会がございま した。それで，一点だけご質問をさせていただきたい のですが，環境教育，環境学習についてですが，私は， 工場でこういうパンフレットを使って, 工場幹部に一 応こういう動きだということを説明するのですが，こ ういう問題というのは, 子供の頃からかなり地道に教 育しないと，なかなか浸透できないのではないかなと いうことを考えているわけです。具体的に教育につい て，文部省も含めてですが，環境教育について，どの ような考えを持っておられるか，何かありましたらお 願いいたします。 
小林 大変良い質問です。子どもの環境教育はどうな つているのかということでありますが, 環境基本計画 自身が, 大変分量を割いて, 環境教育, 環境学習の方 針を書いています。これも，本邦初演です。中間的な とりまとめをしましてその後，国民からの意見もたく さんあった部分でもありまして, ほぼ全面書き直して いるという点でも大変ユニークでございます。

その中では, 玄人筋の人が見ればおもしろいことも いろいろ書いてあります。たとえば，環境問題につい ては, 専門の科目で教えるのか, 総合科目で教えるの か, どこの科目でも全部教えるのかとか，いろいろな 議論があったのでありますが，それについていえば， たとえばどんな科目でも全部教えるというような方針 でいこうと，いろいろなことが書かれています。

それで私どもも実は小学校, 中学校レベルあるいは 高校レベルの環境教育, 環境学習というのは大事だと 思っておりますし, 文部省とは大変いい仲でありまし て, 指導要領等々にもずいぶん環境の問題というのは 入ってきております。むしろお父さん，お母さん方の ほうが今や, 知識として遅れているぐらいです。私ど もが昔はオゾン層とかそういうのはあったのは学校で も習いましたが, 現代は本当に相当細かいことまで学 校で教えていることにびっくりするぐらいです。

さらにそれをもっと進めて教科書的な知識というだ けではいけないのであり, 子どもの場合には, やはり 体験ができるということが非常に重要であります。文 字だけ，頭だけの知識でなく，私どもとしては，体験 学習ということに大変力を入れております。そのため にはどうしてもハード的なものもいるわけですね。た とえば，学習センターをつくるかというようなことで すね。そういうことにもかなり力を入れるつもりです し, 来年あたりには, 各地で体験学習といったものが 起こってきていますから, ナショナルネットワークと いうようなものもつくっていこうというふうに思って おります。

さらに，つい最近発足しましたが，子どもエコクラ ブというのです。4 5人お子さま方が集まって，大 人のサポーターがついたら，それがその登録をして， ちゃんと会員証ももらえて，いろいろ 1 年間にやる結 構厚いマニュアルを送ってもらえるようになってきま した。それをやると，アースレンジャーとかなんかい う 1 年後には認定を受けられるというような, 大変お 子さまが喜んで体を動かしながら環境問題に取り組ん でいくことのできるクラブが発足しました。大変好評 のうちにお申込みが殺到しているという段階でありま す。
その他, 私どものそのものについていえば，この環 境基本計画というと, 自身も子どもに伝えていかなけ ればいけないということで，一つには子ども版の環境 基本計画というのをいろいろなところでつくってみた らどうか。たとえばマンガで「どらえもん」のなんと かとか, つくってみたらどうかということで, そうい うふうに作る際のマニュアルといいますかね，この基 本計画のどの部分をどういうふうに子どもに訴えてい つたらいいかというのを特別の教育の専門家の方々に 集まっていただいて, 70〜80 頁の薄いものですが, マニュアルを作ったところです。

そういう意味では, 環境教育というのは, 大変大事 な,つまりこれからは自己責任をもって, 自主的, 積 極的に環境対策をやっていく人を育ててゆかねばなり ません。そのためには, 十分なやはり情報提供, 知識 といったものをもって, 重要な政策ツールというふう に位置づけて一生㦟命やっているところです。

質問（B 氏）お聞きしたいのですけれど，政府の中 での，たとえば今，通産やら，建設やらがあって，そ の下のほうに環境があると思うのですけれど，将来的 に，たとえば地球全体をきれいにしていく場合は，環 境の部門が大きくなってこないといけないと思うので すが, 今後, 政府の中でそういうふうな方向に動いて いくかどうか，そのへんをお聞かせいただきたいと思 うのです。

小林 大変難しい質問ですね。まず，環境庁が建設省 や通産省の下かどうかについては，まあ，争いのある ところでございます。ただ，相手のいない場で，私が 勝手に都合のいいことを言っても，悪く言えば犬の遠 吠えというのか，よく言えば自己満足というか，そう いうことでありますから，また他の人様の話ですから， あまり言いたくないと思いますが，1つだけ申し上げ ておきますと，学生の会社訪問とかは当然進んでいる と思いますが, 官庁にも学生さんの人気がある。そこ で最近の大学生のアンケートを採ったところ, 国の機 関の中では, 環境庁は 3 番目の人気であるということ であまりして，大変高く位置づけられています。1番 目と 2 番目が建設省と通産省かどうかについては私は 知りませんけれど（会場笑い）。それはおいておきま しょう。

私どもとしては，環境の価値というのは，いわばい ろいろな経済活動の器を決めるものでありますから， 何かほかの価值の比較考量として，こっちがあるから 環境のほjはちょっと譲っていいやという話でもない と思っているのです。そういう意味でいいますと,こ と環境保全に関していえば，はやり環境基本法なり, 
国の環境基本計画が最優先をされるべきだということ でありまして，たとえばお配りしたパンフレットの中 でも, 各種計画との連携というようなことが書いてあ ります。

因みに, ごくごく最近, 閣議決定した国の行動計画 などについて言えば，通産省さんも建設省さんも喜ん で一応賛成をしていただいております。官庁営繥とい うのは今まで，あまり環境の観点では語られなかった のですが，しかし，はっきりと環境問題を解決してい
く手段として, 官庁営繥を使っていくということがは っきり書かれているわけです。やはり時代の進歩だと 思いますし，そういう個々の価值のどっちかが上とか 下とか，それはそういう次元の話でもないのかもしれ ません。

司会 まだ，何かとご質問もあるかと思いますが，時 間がまいりましたので，ここで講演を終わらせていた だきたきと思います。最後にもう一度, 盛大な拍手を お願いいたします。(拍手) 